Review

\title{
Taxonomic Review of Classical and Current Literature on the Perennial American Family Forest Problem
}

\section{Thomas J. Straka}

Department of Forestry and Natural Resources, Clemson University, Box 340317, Clemson, SC 29634-0317, USA; E-Mail: tstraka@clemson.edu; Tel.: +1-864-656-4827; Fax: +1-864-656-3304

Received: 19 May 2011; in revised form: 12 July 2011 / Accepted: 5 August 2011 /

Published: 25 August 2011

\begin{abstract}
One of the fundamental issues in American forest policy has been the small forest ownership problem. Early in the twentieth century, it was called the farm forestry problem, later, the nonindustrial private forest problem, and today, the family forest problem. Family forest owners are thought to manage their lands in a suboptimal manner resulting in low forest productivity relative to other ownership groups. This can lead to future timber supply problems. The exact nature of the problem, especially its social and economic basis, was a common subject of early forestry research studies. This article includes many of the major nonindustrial private forest or family forest studies, from early to current, and classifies them both by themes used by other authors and categories that relate to major research areas in the current literature. A major focus of this literature deals with promoting management on family forest holdings and possible land management incentives and disincentives. Natural trends in family forest ownership, like parcelization, also impact upon forest management opportunities. By developing a taxonomy that classifies these studies by research objective, methodology, owner motivation, and problem definition, this article serves to organize the family forest literature in a manner that provides a temporal framework for better understanding the historical motivation for and development of family forest research in the United States.
\end{abstract}

Keywords: nonindustrial private forest; NIPF; family forests; private forests; small forests; farm forests; NIPF problem 


\section{Introduction}

One of the fundamental and perennial issues in American forest policy has been the small forest ownership problem [1-5]. It surfaced early in the twentieth century when nonindustrial private forest (NIPF) or family forest owners were seen to manage their lands in a suboptimal manner resulting in low forest productivity relative to other ownership groups. Poor forest management on these NIPF ownerships was projected to result in future timber supply problems [6-8]. Forest policymakers knew that two-thirds of American private forest land was under family and individual ownership, necessitating public policies to encourage proper forest management on these lands [9-11]. During the first decade of the twentieth century, the concern was over concentration of private timber ownership among a few large timber companies and railroads, and, after World War I, the focus changed to proper management of private forests in terms of protection and forest renewal [12].

Forest management on small private ownerships, later called NIPFs, and today family forests, is a fundamental problem in American forestry [13-19]. The topic still forms a significant part of American forestry research literature [20,21]. One bibliography presented a "reasonable sampling" of the NIPF literature from the 1940s to about 1982 and included over 1,300 citations [22]. Much of this early NIPF literature is in state university experiment station publications, USDA Forest Service publications, minor journals, and trade magazines [22]. Modern computer search engines often do not locate these references and many research articles on family forests do not mention the early NIPF research studies. Plus, this literature is not neatly organized and it is difficult to classify the early studies in terms of relationships to current research efforts. This article includes many of the major NIPF studies, from early to current, and classifies them both by themes used by other authors and categories that relate to major research areas in the current literature. The objective is to offer a thorough set of references on the NIPF and family forests that includes the major studies over time presented through a classification system that will allow researchers to identify key studies that relate to current family forest research topics.

The debate over management of private forest land initially centered on federal regulation of forestry practices or, alternatively, some sort of federal-state cooperative effort to ensure proper forest management, especially in terms of fire protection and reforestation [23]. In 1920 a major USDA Forest Service report to the U.S. Senate found "the kernel of the problem lies in the enormous areas of forest land which are not producing the timber crops that they should" and urged legislation "which will permit effective cooperation between the Federal Government and the several states in preventing forest fires and growing timber on cut-over lands" [24]. The U.S. Congress settled the argument with the passage of the Clarke-McNary Act in 1924 that authorized federal-state cooperation in forest fire protection, tree planting, and forest extension [25]. A second major USDA Forest Service report in 1933, the Copeland Report, continued to stress timber depletion and exploitation by the private forest owners, but suggested state-federal cooperation and public aid to private forest owners to encourage rational forest management [23]. By 1948, small forest owners were identified as "the heart of the problem" [26]. Key concerns were the lack of technical knowledge by forest owners and the problem of small average tract size. The picture in 1948 was defined as "largely one of mismanagement, of exploitation on millions of small properties adding up to exploitation on a grand scale" [26]. At around the same time, the first research literature on the NIPF problem was being published. 


\section{Classical NIPF Literature by Major Contribution to Knowledge}

Until about 1940, little research had focused on the small ownership problem. It was usually referred to as the farm forestry problem, as small woodlots attached to farms accounted for the largest share of the ownerships [27-33]. Over time, the problem became one of just small ownerships, but the USDA Forest Service still collects farm information on its survey of family forest owners [34] and farms still continue to be identified as part of the problem [35]. Until relatively recently, the USDA Forest Service inventory unit categorized private ownerships, except forest industry lands, as "farmer and other miscellaneous private" forest land [36]. Over the first few decades of the twentieth century, the focus of the forestry problem shifted from the concentration of timberland ownership in the hands of a few timber barons to cut-over private forests that were moving into smaller private ownerships. Growing stock on these small forest ownerships was much less than on comparable public or industrial ownerships and management of these small forests became an issue. The issue continues to today. Forest policy has produced government incentives and regulations to ensure proper management of small, privately-owned forests, so that they produce an adequate contribution to the nation's timber supply.

In one of the earliest NIPF landowner studies, Stoddard found most of the owners of small forest holdings lacked an interest in long-term forestry and were not actively managing their properties [37]. Stoddard looked at the cut-over forest area of Northern Wisconsin that followed a pattern of being sold off in small parcels after an area had been logged, resulting in tracts too small for efficient forest management. Four factors were identified that influenced a forest owner's decisions on forest management: “(1) Familiarity or lack of knowledge regarding cutting, transportation and marketing of forest products; (2) Proximity of residence to land in order to permit regular supervision over management operations and harvesting forest products; (3) Relative returns from time expended in management of forest lands as compared with other regular occupation of owners and risks involved; (4) Size of holdings, value and amount of merchantable timber and relation of taxes, interest, and other carrying charges to annual or periodic incomes." Hundreds of additional NIPF landowner studies over the next 70 years would confirm the importance of these factors. Stoddard also identified seven important reasons that made many forest owners uninterested in forest management as a permanent venture: "(1) Too large an amount of capital needed; (2) Slow growth and low interest rate; (3) Slow turnover of capital; (4) Lack of dependable markets and credit facilities for going forest enterprises necessitate clearing of timber to liquidate investment; (5) Management and operating difficulties (especially in logging by absentee owners); (6) Long periods between incomes; (7) High degree of risk due to fire, insects, diseases, and trespass for which no insurance exits to cover losses."

A theme in many of the early studies of NIPF lands and owners was that forest industry lands were more actively managed and had higher levels of pine timber production (based on an arbitrary pine stocking index) than the small private forest tracts [38-40]. These same studies explored the characteristics of NIPF owners, such as owner occupation, education, gender, financial position, tenure of ownership, management objectives, tract distance from residence, and size of forest holding (and some studies related these characteristics to forest management practices). These early studies identified four approaches to increase productivity on private lands: (1) more aid to the productive landowners (mainly forest industry) in terms of better forest fire protection, forest tax provisions, and 
increased tree planting; (2) more education and demonstration programs for NIPF landowners; (3) more cooperation between public agencies and forest industry with NIPF landowners; and (4) acceptance of more public regulation of NIFP lands.

Several authors attempted to classify this early NIPF research literature. A basic system of classification is relatively easy to develop as a series of themes dominated NIPF literature and similar studies were implemented across the country, usually on a state or regional level. Table 1 shows the pattern of research that developed and a simple classification system developed by an early researcher [41].

Table 1. Early nonindustrial private forest (NIPF) research literature classification scheme by study objectives [41].

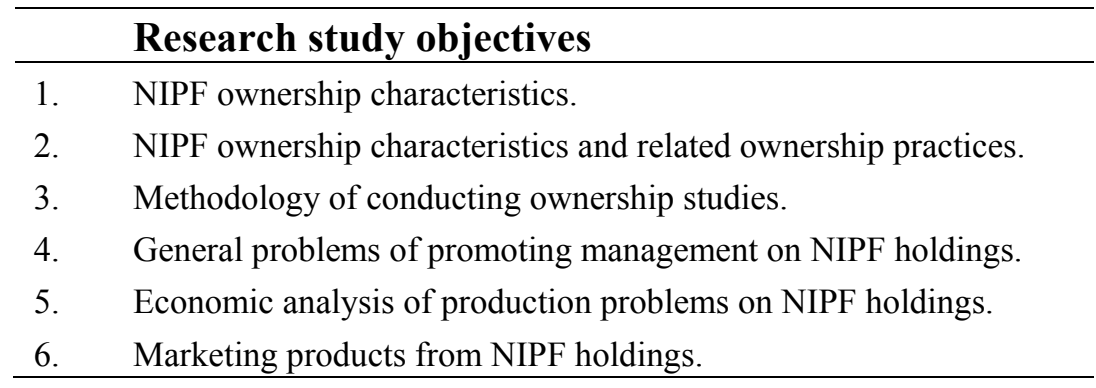

The classic NIPF research literature is identified and discussed below. McMahon, who developed the classification scheme in Table 1, identified the earliest classical studies [41]. This discussion will expand the classification to the late 1970s when the NIPF problem was generally redefined and the focus of NIPF research shifted away from the small woodlands, landowner characteristics, and regional studies [11].

\subsection{Classical NIPF Ownership Studies}

This group of studies focused on NIPF landowner characteristics, like occupation, education, gender, management objectives, income level, asset level, and land tenure. Related forest management practices were sometimes discussed, but the next classification will include those that attempted to statistically correlate owner characteristics with management practices. This class includes only studies that did not attempt that correlation. The early study by Stoddard [37] is an example of this type of study; it was a simple survey of characteristics like tract size, length of ownership, how the land was acquired, ownership objective, owner attitude towards public assistance for better forest management, and ownership pattern. It described the owners and their forest holdings, but made little attempt to establish relationships with forest management practices on the land.

The USDA Forest Service published many of the basic NIPF landowner characteristic studies and continued these studies through the end of the twentieth century. These tended to be state-level studies. One of the first was a study in New England that reported on how the forest properties were acquired, length of ownership, and the owner's occupation, age, and residence. The study also listed distribution of the forest land by size of forest holding; this characteristic would prove to be significant in later research. It also discussed financial returns as a factor in ownership [42]. Several state-level studies came out of the California Forest and Range Experiment Station in the 1950s [43-46] and out of the 
Central States Forest Experiment Station in the 1960s [47-49]. Major publications continued to be produced, mainly in northeastern and midwestern states [50-73]. These studies formed the statistical framework for most related NIPF research for about a thirty year period. Then the shift was to a national study with state-level results that is still in use today [34].

While the national studies were proceeding, many state-level studies complemented them. These were performed mainly at the state agricultural experiment stations. Classic state-level studies were conducted in Missouri [74], Texas [75,76], Pennsylvania [77], Arkansas [78], Louisiana [79,80], Georgia [81], Washington [82,83], Oklahoma [84], South Carolina [85], and Alabama [86]. It is difficult to distinguish between NIPF studies that report solely on characteristics, attitudes, and objectives and those that relate these characteristics to forest management practices.

Even today, as part of more sophisticated NIPF studies, the basic characteristics of NIPF owners and forest are reported, but this most always is followed by an analysis of resulting forest management practices. The following section addresses the studies that focused on these resulting behaviors. Note that these categories were never intended to be mutually exclusive and some judgment was necessary in terms of classification and assignment to a category.

While a pine stocking index was often used in these studies to measure quality of forest management, other general schemes were used to access management quality. In a Central Mississippi study timber management was rated by most recent cutting practice (whether it improved, maintained, or harmed the timber stand) and quality of fire protection [40]. Occupation was one of the most common early characteristics noted in NIPF surveys and the focus was usually on farmers. A Louisiana study classified forest owners by three classes: those that owned both forest and agricultural land, those that owned forest land with no farm land attached, and those with timber processing facilities [38,70]. Early studies placed great weight on farm ownership [42], but gradually other occupational categories like professionals and executives gained importance [55-58,79]. Education was often identified as a key variable that influenced the level of forest management [47-86]. However, education level is likely to be correlated with other variables like occupation, financial position, and size of forest holding. It was difficult to determine which survey variables exerted the most influence, as many were interrelated.

\subsection{Classical NIPF Ownership Characteristics and Related Forest Management Practices Studies}

This class of NIPF research study developed alongside the more basic owner and forest characteristics studies. They represent a higher level of research as they attempted to correlate these characteristics with forest management performance. Since performance was evaluated, it was necessary to establish standards of what the desired levels of forest management activities would be on NIPF holdings. The very early studies in this classification were well-described by White [87].

Pine stocking index was used in the earliest studies in the South as an indicator of performance. Pine productivity was the standard and type and size of forest holding were related to this standard [38,39]. The final report on this study compared poor practice on NIPF lands to the better managed industrial lands. NIPF lands were "producing less than half the pine which the land was capable of growing" [88]. The main problem was a "lack of understanding" among the NIPF landowners; education and demonstration programs were recommended to better inform these landowners [88]. A 
USDA Forest Service report described forest management on the NIPF lands as on a "submarginal level" due to "destructive cutting practice" [89,90]. These results encouraged more research on NIPF management practices and landowner characterizes that related to management practices [40,91].

Asset and financial position were gradually recognized as crucial and studies started to suggest occupations that enhance financial position tend to include owners with the capital to manage forests [41]. Age of forest owners was also a common survey question. Forest owners tended to be old and land tenure and inheritance became issues [47,48]. Level of education has always been shown to be positively linked to better forest management, probably due to its correlation with forest owner financial position [41,50-54,72-74]. Other variables that were usually in forest owner surveys were length of land tenure [40], distance of residence from the forest [39,75], proximity to an example of well-managed forest land [39,77], primary objective of management [40,71], understanding of forestry concepts [38,76], and size of forest holding [41]. One obvious statistical problem associated with most of these forest owner characteristic variables is that many of them are correlated with each other, limiting analysis opportunities.

State-level or smaller area studies of the NIPF problem began about this time. Many addressed the factors that affected small woodland management and were often based on "standards of good management" [92]. The Tennessee Valley Authority initiated studies to determine why some NIPF landholdings were managed better than others. They designed performance standards based on cutting systems, logging methods, fire protection, and growing stock. Economic status was a major characteristic impacting forest management, with poor management expected from landowners with low income and financial difficulties [93-95]. Similar studies were performed in Louisiana [96], Texas [97], and Wisconsin [98].

European studies in the 1960s and 1970s showed that small forest tract size was not just an American problem. Many small forested tracts were controlled by unintentional owners, who had limited capital, saw levels of potential return that did not justify the required management practices, and often had to deal with inadequate markets for their forest products [99]. Gradually, the social dimension of the NIPF problem gained importance and the motivations of NIPF owners were often the focus of research studies [100-103]. Most NIPF landowner studies tended to include statistical correlations with practice adoption and forest owner characteristics. One broad study that included an analysis of nine NIPF studies noted that most of the literature was "descriptive in nature" and was limited in addressing NIPF owner characteristics and attitudes [104].

The 1960s found researchers questioning the value of additional studies of NIPF owner characteristics [105]. Issues like absentee forest ownership expanded the discussion [106-108] and a strong emphasis developed on the social factors that influence NIPF owners [109-115]. There was still a strong focus on an NIPF problem, but its definition was seen as more than NIPF landowner characteristics [116-120]. Many researchers were questioning the foundations of the NIPF problem and the criteria used to evaluate it [121] and by the 1970s and late 1980s the problem was even being called a myth [11,122-125]. While the number of NIPF landowner attitudes and motivations studies tapered off during the 1960s, they still are being produced today. Gradually, they moved from attitudes and adoption of practices to specific practices like harvesting and regeneration [126-133]. Some of these studies included interesting literature reviews that discussed the progression of NIPF research [134]. 
While these types of studies are rare today, there still are plenty of NIPF studies that contain data on forest landowner and tract characteristics. However, they tend to use much more quantitative approaches like economic analysis and regression techniques [135-142]. Critical reviews of the early studies did much to eliminate the reports of owner characteristics that lacked analysis and led to the more modern, quantitative NIPF studies [143].

Royer criticized these studies in 1979 by analyzing the dependent variables used to judge landowner performance, the independent variables that determined landowner behavior, and how these related to timber supply [144]. He concluded that these early studies might be misleading to forest policymakers. The NIPF studies tended to use dependent variables derived from "publicly desirable" rather than "individually rational" performance standards [144]. In addition, many studies identified "psychogenic determinants" of forest landowner behavior, rather than the more important "sociogenic determinants." Psychogenic determinants originate in the mind or are influenced by the emotional processes, while sociogenic determinants originate from or are influenced by social factors. "This has led to vast literature on landowner characteristics and attitudes, but has provided little conclusive evidence on the relationship between landowner behavior and the availability of timber" [144].

Regarding Royer's first criticism, the very earliest studies [38-40,42,88] used a pine stocking index to differentiate between owners who practiced good forestry and those who practiced poor forestry. These studies had a basic assumption that all forest landowners should practice intensive forest management for timber production, irrespective of the owner's economic position or goals of ownership [144]. This served to distort the NIPF problem. Regarding the second criticism, many of the studies in this category focused on psychogenic determinants of landowner behavior, like age, education, race, and occupation, and ignored sociogenic determinants [144]. Not surprisingly, asset or financial position (or a proxy for asset position, like size of forest holding) often was found to be an important determinant of landowner behavior [13,42]. Plus, a number of studies showed that many NIPF owners did not primarily focus on timber production, but had major ownership objectives related to non-timber outputs like wildlife and recreation [51,92,104,105,112,134,145-159]. Even forest landowners' stated intentions were found to differ from later forest management practices on the ground [152-155].

\subsection{Methodology of Conducting Ownership Studies}

There is not much literature on the methodology of conducting forest owner studies. Rather, it is included in the methods sections of most early studies. A few specific studies, however, is worth mentioning. The issues raised earlier by Royer are interesting [144]. In developing NIPF landowner study methodology, what were the measures of performance used and which independent and dependent variables were used in the studies? Early methodology centered on data availability, relevant owner characteristics, subjective measures of management intensity, and obtaining owner management objectives [14,160,161]. While not concentrating on ownership study methodology, some authors proposed areas of research need and suggested possible methods [162,163]. Various USDA Forest Service NIPF studies discussed methodology [164] and some large conferences addressed data needs [165]. The most current major NIPF or family forest owner study has a detailed discussion on methodology $[34,166]$. Another issue was use of formal models to examine landowner 
behaviors [167]. Many authors used a profit-maximizing assumption, while the multiple objectives of family forest owners might be better defined with an assumption that these owners are utility-maximizing [168-170].

\subsection{General Problems of Promoting Management on NIPF Holdings}

The general problem on NIPF ownerships started out as a timber supply problem. Mismanagement of NIPF lands resulted in less than optimal forest management intensity and reduced national timber supplies, with the projected result of a timber famine [14-18,121,143]. Some studies addressed why management intensity was below par on NIPF lands and what the underlying factors were that resulted in underperformance [171]. Others addressed just how important timber production was to NIPF owners [172] or whether NIPF owner stated intentions for forest management matched actual practice on the ground [173]. How American forest management on small forest holdings compared to that in European countries, especially Sweden, also became a research topic [174-182]. Some studies considered economic aspects of small forests [183-194], suggesting education and demonstration programs [195-200] or technical assistance [201-208] as means to encourage forest management. Even factors like ownership change impacted potential timber supply on NIPF forests [209-218]. The fundamental question was what actually motivated NIPF owners to produce timber [219-230]. While the NIPF problem was generally accepted, occasionally, the linkage between NIPF forest holdings and potential timber supply problems was questioned [5,13,186,214,231-235].

One general issue surfaced that still claims importance. Size of forest holding limits the economies of scale available to a forest owner to attain economic efficiency in the establishment, management and harvesting of timber [236-240]. In addition, size of forest holding has been shown to be closely correlated with the forest owner's asset position. This affects their availability of capital to invest in and manage forest land [1,13]. A classic study in Sweden [174], and other studies in the United States, focused on the effects of tract size [241-247]. The most recent NIPF studies and reports continue to examine this variable [34].

A second research issue that has generally been in the NIPF literature is now gaining importance as urban development takes place in the United States [248-254]. Parcelization is the decrease in average NIPF tract size as owners sell or gift parcels from their holding or divide it among multiple heirs at their death. As urban centers expand, parcelization becomes most pronounced at the urban/rural interface. As average tract size decreases, the matter becomes a special case of the size of forest holding issue. Not only are the economies of scale inherent to the larger tract lost, but given the nearby development, the new owners may not hold timber production as an objective of their ownership. The early NIPF literature referred to this issue as fragmentation $[255,256]$, but it should not be confused with the more current issue of forest fragmentation which refers to the loss of forest cover and wildlife habitat as NIPF land is divided among more owners or converted to more developed uses [257].

An important study in 1970 put a new perspective on many NIPF landowner studies. It noted that the stated intentions of NIPF landowners on surveys often differed from their actual practices at a later date. What forest owners planned to do with their timber could change as the timber became more valuable or the owners faced unexpected financial needs over time [258]. The reliability of the hundreds of earlier NIPF landowner studies came under question as other researchers looked at actual 
practice on the ground [136,140,152,172,173,191,200,232,259-265]. Motivations of NIPF landowners remain controversial to this day, especially when financial incentives are involved. Many of the fundamental means to motivate NIPF landowners are based in financial and economic options; these studies are discussed in detail in the next section and include financial motivations like cost-sharing, tax incentives, and the Forest Stewardship Program.

\subsection{Economic Analysis of Production Problems on NIPF Holdings}

\subsubsection{Early Forestry Assistance for the NIPF}

Since U.S. forest owners were first becoming interested in long-term management of their forest resources, researchers have been suggesting ways to improve the management and sustainability of NIPF land. Both financial and non-financial incentives have been offered to owners, but three approaches have consistently been found to lead NIPF owners to apply sustainable forest management practices on their land: technical assistance, cost-shares, and programs - such as the Forest Stewardship Program (FSP) - that put owners in direct contact with a forester or other natural resource professional [266].

The early literature usually suggested which incentives might be most effective. Eventually, as forestry incentive programs were established, their effectiveness was evaluated and the three approaches mentioned above tended to dominate the incentives offered. Modern programs, like the FSP, tend to be multi-dimensional in terms of approaches used. The debate as to which approaches and programs are most effective is still ongoing in the literature [267-275].

Financial and technical assistance programs for conservation practices developed during this period and followed the pattern of being primarily concerned with timber production. Some of the earliest federal assistance to the NIPF owners was authorized by the Clarke-McNary Act of 1924. It provided cooperative assistance in wildfire protection, seedlings, and technical advice. The Agricultural Conservation Program (ACP) was authorized under the Soil Conservation and Domestic Allotment Act of 1936 and provided for federal cost-share assistance to farmers and ranchers for approved conservation practices. This was a soil and water conservation program that shared the costs of forestry practices like tree planting, timber stand improvement, shelterbelts, firebreaks, and fencing for protection against grazing. The Conservation Reserve Program (CRP) of the 1950s, commonly known as the Soil Bank, had a similar goal of encouraging farmers to convert marginal crop land to forest or grasslands [12].

Even the earliest NIPF landowner studies discussed the importance of forestry incentives. One of these studies considered the post-world War II future of NIPF land in the cutover forests of the Northern Lake States [37]. The author realized that technical assistance was a necessity and suggested that county agricultural planning committees may have a role in encouraging forest management. The problem of economies of scale was recognized with a suggestion that public forestry agencies might assist in developing management organizations that could provide technical and management services suitable for these owners. Other forestry incentives, such as special tax laws, long-term rehabilitation credits, and forest insurance were seen as not being effective in encouraging forest management.

Other researchers evaluated cutting practices in Louisiana and noted that the public was demanding forest conservation from private owners and ought to be willing to share the costs of this forest 
conservation [39]. They recognized that cutting practices needed to be improved in the state and suggested four approaches to better forest management: (1) extension of aid to those demonstrating an interest in forest management (forest fire protection, fairer tax laws, and better access to tree planting stock); (2) increased public education and demonstration programs (increased funding for programs under the Cooperative Farm Forestry Act of 1937); (3) forest conservation districts to unite the forestry community and improve attitudes towards forest management; and (4) public regulation of private forestry. Another typical early NIPF study evaluated cutting practices and fire protection [40]. Timber management practices in Mississippi were rated as poor and NIPF owners were asked if public management assistance, forest credit at low interest, or lower taxes on forest land would help to improve management practices. Public management assistance was the only one of these three means of improvement that owners thought might be effective and even then only one-third of owners expressed an interest in receiving such assistance. Further, only a few of that one-third expressed any willingness to pay even a nominal fee for the service.

In Northern Michigan, farmers holding about 60 percent of the NIPF owners did not know that ACP payments were available for forestry practices [276]. Almost half of the applicants for ACP forestry practices incentives stated that they would have undertaken the forestry practices without incentives. Four percent of farmers knew about and were qualified for ACP payments, but did not apply, mainly due to the time cost of the paperwork. The authors described the lack of knowledge about the assistance programs as "striking."

A Central Wisconsin study found only a nine percent participation rate in the ACP program [98]. Of non-participants, 24 percent were not interested in forestry, 17 percent did not know about the payments, 16 percent did not have time to participate, and six percent said there was too much "red tape". There also was low participation in the ACP in Southwest Arkansas [78], where 30 percent of eligible landowners did not know the program existed and only five percent participated in ACP forestry practices. Of those that knew about the program, three percent thought it was not worth the paperwork and 15 percent objected to subsidy programs in general.

Researchers studied the response rate to forestry programs in Southern New York and identified only two ownership characteristics that might be helpful in predicting participation in public programs offering assistance to landowners in planting and timber stand improvement work: amount of forest land owned and the owner's asset position [277]. This implies that minimum-cost timber production results from forestry assistance efforts being concentrated on the more well-to-do forest owners, which conflicts with the use of forestry programs as income-assistance measures. Another study found property tax modifications (like yield and other deferred tax plans) to encourage forest management by private owners, favorable capital gains treatment of timber income, and subsidy payments under the Agricultural Conservation and Soil Bank programs had limited influence on forest owners [171].

In North Carolina and Georgia, 80 percent of the woodland owners who planted trees (the most popular program under the ACP) did not even know that the program existed [114]. Many would have planted with or without aid. Some felt unsympathetic toward all public-aid programs or disliked the terms of the planting program. One study reported on the use of ACP payments over the Eastern United States based on nine forest landowner studies [104]. In only one state did more than 10 percent of owners participate in the program. The major reasons given for not participating in order of importance were: "not interested in forestry, unaware the payments were available, lack of time 
to do the work required, unsympathetic to program, and to much 'red tape' involved in making applications." There was no participation in the ACP in Ohio [48]. Over half of the possible participants were unaware of the program. Others reported they were "too busy" to participate. Further, forest taxation did not seem to influence landowner decisions.

Other studies analyzed the economic impact of the ACP on forestry [278]. Two basic premises for the ACP were that the program was needed (justified by USDA Forest Service timber supply studies) and that cost-sharing by the federal government was justified because of the benefits gained by society overall. The purpose of the ACP was to assist NIPF landowners in conserving agricultural soil, water, forest, and wildlife. Since forest practices contribute to that goal, cost-sharing was approved for practices like tree planting and timber stand improvement. Forestry practices can only be identified in ACP data starting in 1946. ACP expenditures for forestry consistently rose from 1946 to 1956, while overall ACP payments remained uniform. Slightly more than half of ACP forestry cost-share payments went into tree planting, followed by timber stand improvement. Nearly 10,000 hectares were planted under ACP in 1936; by 1958 it had steadily increased to just over 100 thousand hectares. From 1946 to 1958 about 20 percent of all tree planting and about 12 percent of all timber stand improvement in the United States was performed using ACP cost-sharing. The importance of ACF funding for forestry practices declined after this period, especially as alternative cost-sharing programs were developed [219].

On Michigan's Upper Peninsula over 60 percent of eligible woodland owners had heard of public assistance programs for forestry practices. Of owners who knew about the program, about one-sixth had received ACP payments [107]. In the urban fringe area of Michigan two-thirds of woodland owners were aware of the ACP, but only four percent had requested ACP assistance, although once it was explained to them, another 11 percent expressed an interest in the program [255]. The same relationship held over the entire state of Michigan. Over half of Michigan's woodland owners knew of the ACP, but less than one tenth had received forestry a cost-share [115].

There was no participation in the ACP in the Missouri Ozarks [49]. Almost a quarter of forest owners were unaware of ACP forestry practice payments, and nearly 60 percent of the owners who were aware of the program were indifferent to it. Nonparticipants claimed a lack of interest in forestry, a wish to avoid entanglement with government, and a dislike of subsidies. In Iowa, 60 percent of forest owners were aware of the forestry incentives available under the ACP and about one-third were unaware of the property tax advantage for forest land under the Iowa Forest Preserve Law [117]. In West Virginia there was a 31 percent ACP participation rate. The main reason for nonparticipation was lack of knowledge of the program (about 40 percent of nonparticipants did not know about ACP); when ACP and the CRP were explained, 37 percent expressed an interest in participation [112]. In North Carolina 40 percent of forest landowners who replanted trees received direct monetary aid from the ACP or the related CRP [114].

One researcher identified several factors that were related to ACP forestry practices being adopted on NIPF property: owner's occupation, education, the size of the forest property, and the tenure status of the property owner. Practices were most likely to be adopted by owners of larger than average tract sizes and better than average educations [279]. One researcher suggested technical assistance would be most effective if it was leveraged through coordinated management of forest ownerships [280].

Various forestry incentives were being discussed in the literature and applied to the "timber supply problem." Cost-share assistance, technical assistance, and income and property tax deferments and 
abatements were evaluated for effectiveness. Continuing to today there has been much discussion on the merits of these financial forestry incentives. Many studies showed that forest owners would have provided the same forest management accomplishment at their own expense. In situations where funding was poor in a particular year, some forest owners delayed activities like reforestation hoping for public support in a later year (when they would have promptly reforested without the possibility of financial assistance). The early 1970s saw a new forestry cost-share program and increased discussion on the effectiveness of different incentive methods for forestry.

\subsubsection{Forestry Incentive Program (FIP)}

ACP funding for forestry activities was limited in the 1960s and this encouraged forestry interest groups to lobby Congress for a separate forestry cost-share program. In 1973 Congress enacted the Forestry Incentive Program (FIP). FIP was a timber production oriented cost-share program that mainly encouraged reforestation and timber stand improvement [25]. At about this time many states were also developing state-level forestry cost-share programs [281].

Several authors questioned the effectiveness of cost-share programs. One study divided the public approaches for motivating forest owners into direct incentives that provide identifiable monetary benefits to forest owners and indirect incentives (like the Cooperative Forest Management program, university research, and public cooperation programs) [219]. This study noted a lack of knowledge regarding program effectiveness and economic justification. Other researchers discussed obstacles that prevented private forest owners from contributing as much as they could toward national timber production goals [220]. Another study discussed the primary direct costs of a forestry incentives program (expenditures needed to carry it out) and secondary costs (those borne by other individuals or groups in society), urging care in calculating secondary benefits [282].

Some of the first evaluations of FIP occurred in the mid-1970s [283-285]. They noted that prior forestry incentive programs had generally been parts of programs designed primarily for soil and water conservation, while FIP was designed specifically to increase national timber production. The first year's performance evaluation found financial return and total yield increase to be high, on average [285]. A later evaluation of 1979 FIP results found the program was meeting its legislative mandate with significant increases in timber production that earned high rates of return [286].

A South Carolina study "investigated the effectiveness of FIP in terms of the components of its structure; the benefit-cost characteristics of the program; and a regional analysis.... The most popular forest management investments in the program have been: (a) regeneration of southern pine on poorly stocked sites; (b) conversion of oak-pine and oak-hickory stands to pine; and (c) planting on open land.... The success of a county's FIP was found to depend upon: (a) market demands for forest products in the county; (b) number of landowners eligible to apply for FIP cost sharing; and (c) the degree to which the program was promoted.... Based upon intra-state and regional analysis, the study found FIP in South Carolina to be effective" [287].

Other researchers noted that with the advent of FIP, the importance of ACP to forestry had diminished [11]. They discussed major problems of public programs, "The lack of cost-effectiveness measurements and the lack of specific goals at various levels appear to reflect a general philosophy that particular investments need not consider economic criteria as long as they conform to program 
guidelines.” By 1978, awareness of forestry incentive programs was still reported as a problem. In Washington, only one-third of woodland owners knew of at least one cost-sharing program (ACP was best-known). Ten percent of all forest owners had participated in cost-sharing, but 63 percent of those would have done the management practice without the cost-sharing. Only about half of the participants would apply for cost-sharing again. Of those who did not participate, most claimed they did not care for government programs or that they lacked the time. The higher the cost-share rate, the more willing woodland owners were to participate [83].

In studying Louisiana NIPF owners, one researcher found "almost all nonindustrial landowners recognize the need for increasing the productivity of forest lands. However, a satisfactory rate of return is not available to the forest landowner under current conditions.... Some public programs have been developed for nonindustrial forest owners and these programs have improved forest practices.... The most effective forest management programs involving financial assistance for owners of small timber tract have been based on incentives... The most effective accomplishments in forestry to date have been achieved by programs that combined both financial and technical incentives" [134].

Several states have developed their own forestry incentive programs similar to FIP, but funded totally at the state level. Virginia passed a state reforestation program (at the 50 percent cost share level) in 1971 that was funded by the landowner, a severance tax, and the general fund. Mississippi, North Carolina, and South Carolina enacted similar programs. Texas initiated a program funded by forest industry and Alabama one funded by the legislature [288]. One study evaluated the economic effectiveness of Minnesota's private forestry assistance program. "At any rate, the estimate of Division costs of providing aspen harvesting assistance appears to indicate a net transfer of income form the state to assisted landowners (whether it be efficient or not), a small transfer from landowners to the federal government, and no net economic benefit to society at large" [289].

In a national study, NIPF landowners were surveyed concerning their management practices and reforestation decisions [244]. "According to the landowners polled, reforestation decisions on six-tenths of the area harvested would be highly or moderately affected by the increased availability of cost-sharing... The incentives deemed by owners of most of the harvested forest land in the South as likely to influence reforestation decisions were tax adjustments and increased cost-sharing.... Public policies that would offer potentially effective pine reforestation incentives to the owners of a large majority of harvested timberlands were identified as follows:

* Reduced property taxes (to ease the annual financial burden of owning and managing pine).

* Reduced estate and inheritance taxes (to minimize the financial penalties and the need for hasty decisions regarding pineland following the death of the landowner).

* More favorable tax credits and tax deductions (to encourage investment in pine reforestation at the time of harvest).

* More favorable capital gains treatment for timber revenues (to increase the availability of pine reforestation dollars).

* Increased public cost-sharing (to defray partially the high costs of pine reforestation to the private landowner)."

One researcher used an econometric model to evaluate the determinants of reforestation behavior among Southern landowners [138]: "The importance of costs is further reflected in the sensitivity of 
landowners to cost-sharing. Regardless of their financial position, landowners are highly responsive to cost-sharing. For landowners with below-average incomes, this would seem to indicate a way to overcome capital constraints; for landowners with above-average income this would seem to be a way of making the reforestation investment more competitive with other investments. Some substitution of public capital for private capital likely occurs in this latter group, nonetheless the strength of the cost-share coefficient suggest that much of the capital is additive. That is, cost-sharing serves as an inducement to reforest, even among landowners not constrained by capital. The strength of the cost-sharing coefficient suggests much of the increase in reforestation in the South has been stimulated by federal and state cost-sharing. Continuation of such programs would seem prudent in light of the mixed responses to price signals." Other economic studies during this period evaluated the effectiveness of cost-share programs [290-295] and the effectiveness of tax system incentives [296-300].

In the early 1990s, a major shift occurred in federal forestry and natural resource financial incentives programs. The Forest Stewardship Program (FSP) and Stewardship Incentive Program (SIP) were authorized by the Forest Stewardship Act of 1990, representing a replacement of the timber-oriented FIP by a multiple resource program that included timber, wildlife, soils, water, aesthetics, and recreation [301]. The focus for FSP was long-term management for multiple resources and the required development of a multi-resource management plan. Between 1991 and 2006 the program produced over 270 million management plans covering about 12.5 million hectares [302]. SIP was designed to replace FIP and to fund cost-sharing for the practices recommended in the FSP management plans [303].

\subsubsection{Integrated Federal Natural Resource Cost-Sharing Programs}

A set of environmental cost-sharing incentive programs was authorized, starting in the 1990s. These new programs varied in terms of specific natural resources being sustained, objectives, and requirements for funding, like earlier programs' participation rates, varied [304,305]. Even though cost-sharing is now the norm and generally accepted by family forest owners, discussion continues on forest regulation as a means to achieve sustainable forestry on private forests [306,307]. Forest certification is compatible with these cost-sharing programs and may have a positive influence on forest owner participation [308-310]. Most of these programs are managed within the USDA [311]. The programs are described very briefly below.

The Forest Land Enhancement Program (FLEP) was part of the 2002 Farm Bill. FLEP replaced the Stewardship Incentives Program (SIP) and the Forestry Incentives Program (FIP). FLEP was a voluntary program for nonindustrial private forest owners that served as a primary cost-share vehicle. It provided for technical, educational, and cost-share assistance to promote sustainability of nonindustrial private forests. FLEP was administrated at the state-level by a coordinating committee that developed a state priority plan. This plan provided the detail of how FLEP funds are to be utilized, including minimum treatment area, maximum treatment area, and aggregate payments. A forest resource management plan was required for cost-share eligibility. The forestry practices eligible to cost-share were specified in the state priority plan [312].

The Wildlife Habitat Incentives Program began in 1998 as a voluntary program for people who wanted to develop and improve wildlife habitat primarily on private land. Technical assistance and up 
to 75 percent cost-share assistance is available to establish and improve fish and wildlife habitat. WHIP agreements generally last from five to ten years from when the agreement is signed. By targeting wildlife habitat projects on all lands and aquatic areas, WHIP provides assistance to conservation minded landowners who are unable to meet the specific eligibility requirements of other federal conservation programs [313,314]. The Wetlands Reserve Program (WRP) began in 1995 as a voluntary program offering landowners the opportunity to protect, restore, and enhance wetlands on their property. Both technical and financial supports are offered for wetland restoration efforts. Landowners who choose to participate in WRP may sell a conservation easement or enter into a cost-share restoration agreement to restore and protect wetlands. The program offers three options: permanent easements, 30-year easements, and restoration cost-share payments of minimum ten-year duration [315].

The Forest Legacy Program (FLP), part of the 1990 Farm Bill, was created to identify and protect environmentally important private forest lands threatened with conversion to nonforest uses (such as subdivisions or commercial developments). FLP is a partnership between states and the USDA Forest Service and primarily uses conservation easements to control development. Federal funding may be up to 75 percent of costs [316]. The Environmental Quality Incentives Program (EQIP) was reauthorized in the 2002 Farm Bill to provide a voluntary conservation program for farmers and ranchers that promotes agricultural production and environmental quality as compatible national goals. EQIP offers financial and technical assistance to implement structural and management practices on agricultural land. EQIP offers contracts that expire within one to ten years after the last scheduled incentive or cost-share payment. Cost-share can be as high as 75 percent for certain conservation practices [317].

The Conservation Reserve Program (CRP) was established in 1985 as a voluntary program for agricultural landowners. Through CRP annual rental payments and cost-share assistance are available to forest owners for establishing long-term resource conserving covers on eligible farmland. Annual rental payments are based on the agricultural rental value of the land and cost-share assistance is available for up to 50 percent of the participant's costs in establishing approved conservation practices (like tree planting). Participants enroll in CRP contracts for 10 to 15 years [318,319].

One study of the these broad-based conservation programs found that getting the required forest management plan provided two-thirds of participating forest owners their first contact with a professional forester [320]. A like fraction began managing their land for multiple purposes and using practices that were new to them. Their participation in the programs prompted the owners to spend an average of $\$ 2767$ of their own funds for forest management activities, with nearly two-thirds saying they would not done have made the expenditure if they had not received a cost-share [320]. Other researchers identified factors that affected participation in conservation programs [321-324]. Two related NIPF studies noted that broad-based conservation programs and their multiple resource objectives requirement were well-received by forest owners. Timber and wildlife tended to be the most popular of the objectives [325,326]. Forest sustainability and its relation to these programs were analyzed nationally and in a series of regional studies [327-331].

The 2008 Farm Bill produced major changes in forestry cost-share and technical assistance programs. The Bill allowed FLEP — created under the 2002 Farm Bill to combine features of FIP and SIP - to expire. For the first time since 1978 there was no dedicated federal assistance program for private forest landowners. Instead the provisions of EQIP, the Conservation Stewardship Program, and 
the Farmland Protection and Grassland Reserve were modified to include management and conservation practices on family forest lands. The Bill also added the protection of forests from threats including invasive species, insects, and diseases as a national priority for federal assistance and established the Emergency Forest Restoration Program within the existing Emergency Conservation Program [332].

FLP is now complemented by the Community Forest and Open Space Conservation Program. FLP still focuses on conservation and protection of threatened rural forest land, while the new program will focus more on community forest situations. The Healthy Forests Reserve Program is a new landowner assistance vehicle that utilizes 10-year cost-share agreements to promote recovery of endangered and threatened species, improve plant and animal diversity, and enhance carbon sequestration. There is also a new Emergency Forest Restoration Program to assist NIPF landowners in restoring forests following a natural disaster [332].

CRP, EQIP, WHIP, and WRP are still active programs. EQIP now is a major forestry landowner assistance program that fills part of the gap left when FLEP expired. The new Conservation Stewardship Program also allows for forestry cost-sharing and there are specialized programs to enhance wildlife, promote reestablishment of longleaf pine, and to promote healthy forests (for example, protection from southern pine and western bark beetles) [332].

\subsubsection{Current Status of NIPF Research on Financial Incentives}

Technical assistance has long been identified as an effective forestry incentive. A foundational study of forest owners in Mississippi found that owners prefer technical assistance over financial or tax incentives [40]. A recent study of policy tools to encourage application of sustainable timber harvesting practices in the United States and Canada also found technical assistance is the most effective way to encourage owners to apply sustainable practices, followed by cost-share programs [333]. Several recent studies stressed the importance of technical assistance to NIPF owners [334-336] and others looked at general aspects of incentive program effectiveness [337-340]. Two different studies found that direct contact with a forester or other natural resource professional is associated with owners being forest managers [341,342]. Studies cited aspects of the FSP that involve contact with a professional — getting a management plan and technical assistance — as the main things owners like about the program. NIPF forestry incentive assistance might center on management of forests to maintain and improve standing timber values [260,343], management for non-market forest products, such as wildlife and recreation [340], or management for specific stewardship practices, such as reforestation [298].

Not just the traditional cost-share payments were being discussed as means to improve NIPF management. Taxes have always played a role in directing NIPF owners towards improved management practices. Tax incentives include reduced property, estate and inheritance taxes, more favorable tax credits and deductions, treatment of timber income as a capital gain, and more favorable treatment of cost-share payments from public programs [343-353]. Studies have shown, however, that favorable property tax and capital gains provisions have little short-term effect on forest owner behavior [344] and forest property tax programs are only modestly successful in accomplishing their objectives [347]. 
Whether forest owners are aware of financial incentives for forestry and which incentives are most effective continue to be issues in NIPF research. One unpopular option is coordinated management of properties; only a small percentage of owners would consent to this on their land [280,354,355]. A large proportion of owners are unaware that financial and tax incentive programs exist or don't know what the programs can do for them [350-354,356]. In many cases, owners who participate in an incentive would have done the supported practice anyway [357] although the incentive enables the owners to treat additional forest area $[138,140]$. There is little doubt that cost-sharing incentives are positively correlated with reforestation efforts; whether the efforts are secondary, capital substitution occurs, and reasons for forest owner use and nonuse are still questions that remain in the literature [358-361]. One topic of major interest to early researchers, but that rarely occurs in the current literature, is the economic viability of forestry on small "farm" tracts [362-368]. Forestry and timber production as an economic enterprise is a topic that has been fully developed.

\subsection{Marketing Products from NIPF holdings}

Timber marketing was a major subdivision of the economic literature of the NIPF. These studies generally addressed timber marketing practices and institutions. They primarily address NIPF owner level of knowledge of forest management, timber sale practices, local timber markets, and timber prices. Such knowledge issues represent a critical handicap for NIPF owners who are forced to deal with very complex timber sales situations from a position of disadvantage.

Much of the research in timber marketing deals with methods to enhance the NIPF owner knowledge base; in particular, his or her knowledge of timber, timber sales, local markets, factors that impact timber prices, and timber price reporting systems [369-375]. Some studies looked at marketing in a broader economic context, as a contributor to timber revenue [376-379], and marketing mechanisms like forest cooperatives have long been advocated as efficient avenues for forest landowners to overcome small tract size problems [355,380-391]. Forest cooperatives have reappeared in the recent literature as a functional means to acquire economy of scale in forestry operations [392-397]. Forest product marketing has produced some quantitative research [398-400] and most states still provide Cooperative Extension-type marketing advice [401]. The problem of marketing forest products has long been recognized as a practical one and most all of the literature on this subject tends to be "how to" publications of state-level extension services. Many state extension services offer very valuable marketing tools like timber price reporting services.

\section{A Current Motivation-Based Approach to NIPF Landowner Research Studies}

There are many bibliographic sources of NIPF research studies. Most do little to classify the literature as there is a thorny problem of overlap between types of studies. All tend to recognize some sort of NIPF problem, be it forest parcelization, suboptimal timber management, or impacts on timber supply. The thrust of most current NIPF research studies centers on NIPF landowner motivations; or, what are the incentives or disincentives of forest management on these lands? One of the best overviews of this current classification trend was part of a southern forest resource assessment [301]; Table 2 presents the categories used to describe NIPF landowner motivations in that assessment. 
Table 2. Current motivation-based approach to NIPF owner research studies [301].

\begin{tabular}{ll}
\hline & Research study objectives \\
\hline & Objective classification \\
\hline 1. & Ownership. \\
2. & Private owner occupation, income, and education. \\
3. & Ownership reasons and objectives. \\
4. & Owner attitudes, values, and knowledge. \\
5. & Private forest management planning and practices. \\
6. & Land management incentives and disincentives. \\
\hline & Financial and educational incentives \\
\hline a. & Taxes. \\
b. & Government regulations. \\
c. & Government forest management assistance programs. \\
d. & Landowner use of cost sharing. \\
e. & Landowner education and technical assistance. \\
\hline
\end{tabular}

Current NIPF studies will usually emphasize that most of the productive timberland in the United States is controlled by NIPF owners, that the number of NIPF owners is increasing, and that average NIPF tract sizes are decreasing. Most NIPF owners have diverse ownership objectives, values and beliefs. NIPF owners interested in timber production as a primary management objective own more than one-third of all private timberland, so they have a huge impact on the national timber supply. A key interest in most NIPF studies is what motivates these landowners and what affects the decision to harvest timber [301,402]. The study that produced Table 2 extensively cites literature; however, like most current studies, the early foundation literature was not discussed. The literature cited has only three citations from the decade of the 1980s and none earlier. This discussion will include the earlier literature within these current classifications.

\subsection{Ownership}

Who owns America's forest lands? About 11 million private forest landowners control 56 percent of the forest land in the United States (171 million hectares). NIPF owners represent about 92 percent of all private forest owners and control 62 percent of the private forest land in the country. Over 60 percent of this NIPF forest land is in tracts of four hectares or less, but just over 50 percent of NIFP land is owned in tracts of 40 hectares or more [34]. This kind of data does give perspective on the NIPF and has been available since the USDA Forest Service has inventoried the American forest [12,23-26,36,47-73]. This type of ownership data provided the basis of entire NIPF research studies [403]. Selected characteristics of NIPF landowners formed the basis of specialized studies, like on minority landowners [217,218,404], changing ownership classes (especially the implications of forest industry lands converting to timberland investment management organizations and real estate investment trusts) [405,406], and methods of acquiring forest holdings, especially by inheritance [407]. Because forest parcelization is a major current issue, ownership studies now tend to stress size of forest holding relationships [1,13,174-177,236-243] and parcelization of forest tracts [244-254]. 


\subsection{Private Owner Occupation, Income, and Education}

These are basic studies to identify just who NIPF landowners are. There is a fine line between these studies and those that took the attitudes and attempted to correlate them to forest management practices. These studies primarily described the characteristics of NIPF owners; this is almost identical to the first classification in Table 1 and these early studies were described in describing that classification [41-86]. Many current studies contain basic ownership data as background, but today it is usually secondary and not directly part of the research study [218,245,354,356,407-410].

That is not to say detailed information on NIPF owners does not exist. In the past state-level studies offered these details. Now a periodic national survey collects detailed data that is available at the state-level $[34,410]$ and there is little need for other studies. Often when specific NIPF programs are analyzed, state-level NIPF owner demographics are included, but rarely is this main thrust of current NIPF studies.

\subsection{Ownership Reasons and Objectives}

Why do NIPF owners choose to own forest land and what are their related management objectives? This classification is nearly identical to the second category in Table 1. Unlike basic survey of NIPF owner characteristics, surveys to determine motivation for ownership and intention of ownership are still common. This relates back to the underlying problem of timber supply; will NIPF owners be motivated to produce timber? These studies stress stated intentions of management, both reasons for owning forest land and intentions for forest management practices based on those intentions [87,135]. The validity of stated intentions were questioned in the late 1970s [172,173,257-264] and the correlation between stated intentions and actual practice is still considered suspect.

Often, the reasons for ownership and management objectives are tied to the current problem of forest parcelization and the related problem of size of forest holding [236-254]. Historically, these patterns and reasons for ownership have been clearly identified as the foundation of any NIPF or family forest problem. Foresters at a 1959 convention identified the economic patterns that impact small forest tracts and discussed options to make management of these small holdings more economically feasible and means to provide technical assistance in order to influence these forest owners and their forest management decisions [411-414]. Timber production is a primary management objective for some family forest owners; for example, for those who tend to utilize federal assistance programs or consulting foresters [324]. The vast majority of family forest owners do not fall into those classes and do not see timber production as something they would emphasize [34].

\subsection{Owner Attitudes, Values, and Knowledge}

Rural people tend to share similar beliefs and value systems on forest management and practices [301,415]. One major difference between rural residents who own family forests and those who do not, is that family forest owners tend to be more likely to have timber production objectives [414]. From the earliest studies of NIPF owner behavior, government regulation was proposed as the most efficient means of ensuring adequate forest management on private lands [12,73,138,290,301,333,335,344,357-359,416]. Concern over private property rights has been 
particularly high in the South, but throughout the United States family forest owners seem to favor a balance between private property rights and environmental protection [335,336,358,416]. Family forest owners do not necessarily agree that proper forest management is the same on both public and private forest lands. Knowledge of family forest owners, especially concerning forestry incentives and technical assistance, has been identified as a factor impacting forest management [47-39,66-69,73,91-94,354,358,359].

Size of forest holding has shown to be strongly correlated with many variables related to forest management, especially forest owners' technical knowledge, educational levels, and attitudes towards timber harvesting. These values and attitudes may be linked to the better asset position of these forest owners [34,231-243]. Family forest owner knowledge of forestry has also been shown to be an important variable affecting reforestation decisions after timber harvest; especially important are knowledge of forestry incentives, technical assistance, and timber prices [173]. Family forest owners are generally disinclined to allow public access to their property [417]. The NIPF and family forest research literature is rich with studies on owner attitudes and values [42-85]. The current literature still addresses forest owner attitudes and values, but the research focus is more likely to be a mathematical model of their impact on forest owner decision-making, rather than a simple survey as in the classical NIPF literature.

\subsection{Private Forest Management Planning and Practices}

Significant focus has been directed to the characteristics of family forests relative to other ownerships and the types of forest management practices being employed on family forests [418]. Much of the research that identified specific management practices on family forests tied these practices to federal or state forestry incentive programs, and thus stresses reforestation and timber stand improvement type activities [280-294,319-324,335,418]. Many of these practices undertaken on family forests, however, are related not to timber production, but to wildlife habitat management, recreation, scenic values, and wetlands [319,324,356,358].

The earliest research focused on timber production foregone due to lack of owner knowledge, insufficient capital, inefficient tract size, or a simple lack of interest [13-15,37-41,66-69]. Consistently, income, education, and ownership objectives were correlated with forest management intensity, harvest and reforestation activities, and the use of cost-share assistance [1,13,14,66,123,301,406,418]. What has never been worked out in these relationships is the correlation between the independent variables themselves [172-175,236-243]. What is the controlling variable? Owner income, asset position, occupation, and education all are positively correlated with size of forest holding. On an operational basis, size of forest holding is an easy statistic to obtain. Does size of forest holding exert strong influence on private forest management practices, or is it merely correlated with other variables that exert that influence? Size of forest holding has been shown to be an excellent proxy variable for these other variables [1,419]. A professionally-prepared forest resource management plan is highly correlated with timber harvesting and reforestation activities, but also is positively correlated with size of forest holding [34,326-330,359]. 


\subsection{Land Management Incentives and Disincentives}

All classifications of NIPF and family owner studies have some sort of classification on forestry incentives and disincentives. These are the tools of the policymaker $[11,12,23,25,420]$. Early private forest policy centered arguments over a "carrot or stick" approach for influencing NIPF and family forest owners; that is, financial incentives versus government regulation. Forestry incentives won out and since then the debate has been over the effectiveness of forestry incentives. This topic was discussed in detail earlier; a brief summary based on Table 2 is below.

Tax policy has been proven to be one of the strongest forest policy tools impacting American forests $[296,421,422]$. Capital gains treatment for timber income, tax treatment of cost-share payments, early amortization of reforestation costs, forest estate taxation, and property taxes are crucial to owners who hold timberland for the production of income; for family forests held for this purpose, taxation policy exerts a huge influence on the types of forest management activities undertaken and overall profitability [290,295-299,326-330,341-354]. Government regulation similarly impacts forest management activities. Regulation can limit the forest land available for some activities, limit forest management options, increase forest management costs, and potentially reduce forest income [23,25,423-425]. NIPF owners generally do not consider government regulation as a serious hindrance to investments in forest management, but the issue of private property rights can be heated in some parts of the United States, especially the South [359].

Federal and state technical and financial assistance programs have a long history as incentives to reforestation and other forest management practices [11,12,15,17,204-221,275-294,301-332,426]. Originally, these programs, especially cost-share programs, had a strong timber emphasis; today the programs broadly support all values from the forest, including wildlife, recreation, wetlands, carbon sequestration, water quality, and aesthetics [292-294,324-332]. Cost-share programs subsidize forest management practices and increase financial returns to NIPF and family forest owners [292-294,301-305,324-331]. Some researchers questioned whether many of the forest management activities would have been accomplished without a cost-share; that is, whether the cost-share was an unnecessary incentive. Studies have both supported and not supported that argument. Some studies suggest that cost-share payments are a secondary factor that encourage reforestation [356-360,427]. Most recipients of cost-share funding were timber-oriented family forest owners [324,327-331,356-360]. Cost-share recipients tend to be better educated and have higher incomes than the average family forest owner. Size of forest holding is one of the best predictors of cost-share use [138-141,356-359,409].

NIPF and family forest owners have been provided additional forest management assistance through education and technical assistance programs. Like other assistance programs, certain landowners tended to receive most of the aid. Forest owners with higher levels of education and income were most likely to receive this type of assistance, and size of forest holding, again, was highly correlated with use of technical assistance [331-336,356-359,422]. The effectiveness of technical assistance and education programs for family forest owners have been debated in the literature; generally they are considered to be moderately to greatly influential in addressing family forest management practices, especially the reforestation decision [332-336,356-358,422]. 


\section{Conclusions}

NIPF and family forest research has followed a pattern over the last 75 years. It has consistently centered on an NIPF problem; that is, these forest lands are managed on a subpar basis that leads to suboptimal timber production. Since this represents a large portion of the nation's timber-growing land, the expected result is timber supply and timber price problems. The pattern that evolved was in simply addressing the NIPF problem. First, the variables that defined the problem were identified. These were the NIPF or family forest owners and the forests themselves. Both had to be described. Then the variables that defined the NIPF and family forests were related to timber production activities. Once basic relationships became established, some prominent factors were identified: size of forest holding was definitely a controlling variable (or was highly correlated to other controlling variables); forest owner intent might not be highly related to actual practice; forest parcelization developed into an important element; and forestry incentives were effective, but controversial, ways to influence forest management behavior on these small tracts. Also, over time, it appeared that timber production was not likely to be the primary management objective on many NIPF holdings, certainly not on the smaller tracts.

The NIPF or family forest research literature can be classified into broad themes. As research progressed, the themes have changed, but maintain the same foundations from the earlier research. The research itself led to a progression in understanding forest owner management objectives, forest owner intent and actual practice, the importance of tract size, and the actual power of financial incentives to impact forest management behavior. Today the focus of NIPF and family forest research seems to be landowner motivation. How will changes in tract size due to forest parcelization change landowner objectives and actual forest management? What is the marginal impact of the various financial incentives available to forest policymakers? What level of government regulation is appropriate to ensure forest conservation and how that interacts with related financial incentives? A sound understanding of today's family forest policy issues requires a firm understanding of the last 75 years of research that defined today's family forest focus.

\section{References}

1. Straka, T.J.; Wisdom, H.W. Fundamental relationships affecting nonindustrial private forest timber output. In Proceedings of Southern Forest Economics Workshop, Charleston, SC, USA, 1-2 April 1982; Southern Forest Economics Workers (SOFEW): Department of Forestry, Mississippi State University, Mississippi State, MS, USA, 1983; pp. 44-57.

2. Duerr, W.A. The Economic Problem of Forestry in the Appalachian Region; Harvard University Press: Cambridge, MA, USA, 1949.

3. Best, C.; Wayburn, L.A. America's Private Forests: Status and Stewardship; Island Press: Washington, DC, USA, 2001.

4. Jones, S.B.; Luloff, A.E.; Finley, J.C. Another look at NIPF's: Facing our "myths". J. Forest. 1995, 93, 41-44.

5. Egan, A.F. From timber to forests and people: A view of nonindustrial private forest research. North. J. Appl. Forest. 1997, 14, 189-193. 
6. Bourke, L.; Luloff, A.E. Attitudes toward the management of nonindustrial private forest land. Soc. Nat. Resour. 1994, 7, 445-457.

7. Foster, B.F. Four horsemen of the NIPF apocalypse. J. Forest. 1982, 80, 706-708.

8. Fernow, B.E. A Brief History of Forestry in Europe, the United States, and Other Countries, 3rd ed.; University of Toronto Press: Toronto, ON, Canada; American Forestry Association: Washington, DC, USA, 1913.

9. Demeritt, D. Scientific forest conservation and the statistical picturing of nature's limits in the Progressive-era United States. Environ. Plann. Soc. Space 2001, 19, 431-459.

10. Smith, H.A. The early forestry movement in the United States. Agric. Hist. 1938, 12, 326-346.

11. Sedjo, R.A.; Ostermeier, D.M. Policy Alternatives for Nonindustrial Private Forests; Society of American Foresters: Washington, DC, USA, 1978.

12. Dana, S.T. Forest and Range Policy: Its Development in the United States; McGraw-Hill Book Company, Inc.: New York, NY, USA, 1956.

13. Duerr, W.A. The small, low-income landholding: A problem in forest conservation. Iowa State Coll. J. Sci. 1948, 22, 349-361.

14. James, L.M. Determining forest landownership and its relation to timber management. J. Forest. 1950, 48, 257-260.

15. Lord, W.B. A reconsideration of the farm forestry problem. J. Forest. 1963, 61, 262-264.

16. Thompson, W.P.; Yoho, J.G. Defining the small forest ownership problem. For. Farmer 1961, 20, 6-8.

17. Clawson, M. Will there be enough timber? J. Forest. 1978, 76, 274-276.

18. Le Master, D.C. Timber supply, nonindustrial private forest land, and the conventional view. J. Forest. 1978, 76, 365-367.

19. Raup, H.M. American forest biology. J. Forest. 1967, 65, 800-803.

20. Carpenter, E.M.; Davis, D.T. Bibliography of the Private Forest Landowner; USDA Forest Service, North Central Forest Experiment Station: Duluth, MN, USA, 1982.

21. Hodgdon, B.; Cusack, C.; Smith, S.; Tyrrell, M. An Annotated Bibliography on the Literature on Family Forest Owners; GISF Research Paper 002-R; Yale University School of Forestry and Environmental Studies: New Haven, CT, USA, 2011.

22. Franklin, E.C.; Miller, M.; Pramik, C. Private Non-Industrial Forestry-The First Hundred Years: An Annotated Bibliography; Research Notes Series 1985, Number 46; Small Woodlot Forestry R\&D Program, North Carolina State University: Raleigh, NC, USA, 1985.

23. Dana, S.T.; Fairfax, S.K. Forest and Range Policy: Its Development in the United States, 2nd ed.; McGraw-Hill Book Company, Inc.: New York, NY, USA, 1980.

24. Forest Service, U.S. Department of Agriculture. Timber Depletion, Lumber Prices, and the Concentration of Timber Ownership, Report on Senate Resolution 311; Capper Report; U.S. Government Printing Office: Washington, DC, USA, 1920.

25. Cubbage, F.W.; O’Laughlin, J.; Bullock, C.S.; Forest Resource Policy; John Wiley \& Sons, Inc.: New York, NY, USA, 1993.

26. USDA Forest Service. Forests and National Prosperity: A Reappraisal of the Forest Situation in the United States; Miscellaneous Publication No. 668; U.S. Government Printing Office: Washington, DC, USA, 1948. 
27. Fernow, B.E. Forestry for farmers. In Yearbook of the United States Department of Agriculture -1894; Government Printing Office: Washington, DC, USA, 1895; pp. 461-500.

28. Clothier, G.L. Forest planting and farm management. In Yearbook of the United States Department of Agriculture-1904; Government Printing Office: Washington, DC, USA, 1905; pp. 255-270.

29. Smith, H.A. The farm woodlot problem. In Yearbook of the United States Department of Agriculture -1914; Government Printing Office: Washington, DC, USA, 1915; pp. 439-456.

30. Chittenden, A.K. Improvement of the Farm Woodlot; Special Bulletin No. 122; Michigan Agricultural Experiment Station: East Lansing, MI, USA, 1923.

31. Murphy, F.T. Managing the Farm Woodland; Circular 207; Pennsylvania Agricultural Extension Service: Pennsylvania, PA, USA, 1938.

32. Mattoon, H.G. Can the farm forester pay his way? J. Forest. 1945, 43, 208-209.

33. Behre, C.E.; Lockard, C.R. Centralized Management and Utilization Adapted to Farm Woodlands in the Northeast; New York State College of Forestry: Syracuse, NY, USA, 1937.

34. Butler, B.J. Family Forest Owners of the United States, 2006; General Technical Report NRS-27; U.S. Forest Service, Northern Research Station: Newtown Square, PA, USA, 2008.

35. Kantola, M. The role of forestry on small farms. Unasylva 1967, 21, 9-16.

36. USDA Forest Service. An Analysis of the Timber Situation in the United States: 1952-2030; Forest Resource Report No. 23; USDA Forest Service: Washington, DC, USA, 1982.

37. Stoddard Jr., C.H. Future of private forest land ownership in the Northern Lake States. J. Land Public Util. Econ. 1942, 18, 267-283.

38. Folweiler, A.D. Forest Land Ownership in Louisiana and Its Influence on Timber Production; Station Bulletin Number 377; Louisiana Agricultural Experiment Station: Baton Rouge, LA, USA, 1944.

39. Folweiler, A.D.; Vaux, H.J. Private forest landownership and management in the loblolly shortleaf pine type in Louisiana. J. Forest. 1944, 42, 783-790.

40. James, L.M.; Hoffman, W.P.; Payne, M.A. Private Forest Landownership and Management in Central Mississippi; Technical Bulletin 33; Mississippi Agricultural Experiment Station: State College, MS, USA, 1951.

41. McMahon, R.O. Private Nonindustrial Ownership of Forest Land; Bulletin No. 68; Yale University School of Forestry: New Haven, CT, USA, 1964.

42. Barraclough, S.; Rettie, J.C. The Ownership of Small Private Forest-Land Holdings in 23 New England Towns; Station Paper No. 34; USDA Forest Service, Northeastern Forest Experiment Station: Upper Darby, PA, USA, 1950.

43. Poli, A.; Griffith, D.T. Forest Land Ownership in Northern Mendocino County, California; Forest Survey Release 5; USDA Forest Service, California Forest and Range Experiment Station: Berkeley, CA, USA, 1948.

44. Poli, A.; Baker, H.L. Ownership and Use of Forest Land in the Coast Range Pine Subregion of California; Technical Paper No. 2; USDA Forest Service, California Forest and Range Experiment Station: Berkeley, CA, USA, 1953. 
45. Poli, A.; Baker, H.L. Ownership and Use of Forest Land in the Redwood-Douglas Fir Subregion of California; Technical Paper No. 7; USDA Forest Service, California Forest and Range Experiment Station: Berkeley, CA, USA, 1954.

46. Poli, A. Ownership and use of forest land in Northwestern California. Land Econ. 1956, 32, 144-151.

47. Worley, D.P. The Small Woodland Owner in Eastern Kentucky: His Attitudes and Environment; Technical Paper 175; USDA Forest Service, Central States Forest Experiment Station: Columbus, OH, USA, 1960.

48. Hutchison, O.K.; McCauley, O.D. The Small Woodland Owner in Ohio; Technical Paper 183; USDA Forest Service, Central States Forest Experiment Station: Columbus, OH, USA, 1961.

49. Farrell, J.H. The Small-Woodland Owner in the Missouri Ozarks-A Close-up; Research Paper CS-10; USDA Forest Service, Central States Forest Experiment Station: Columbus, OH, USA, 1964.

50. Kingsley, N.P.; Finley, J.C. The Forest-Land Owners of Delaware; Resource Bulletin NE-38; USDA Forest Service, Northeastern Forest Experiment Station: Upper Darby, PA, USA, 1975.

51. Kingsley, N.P. The Forest-Land Owners of New Jersey; Resource Bulletin NE-39; USDA Forest Service, Northeastern Forest Experiment Station: Upper Darby, PA, USA, 1975.

52. Kingsley, N.P. The Forest-Land Owners of Southern New England; Resource Bulletin NE-41; USDA Forest Service, Northeastern Forest Experiment Station: Upper Darby, PA, USA, 1976.

53. Kingsley, N.P.; Birch, T.W. The Forest-Land Owners of New Hampshire and Vermont; Resource Bulletin NE-51; USDA Forest Service, Northeastern Forest Experiment Station: Upper Darby, PA, USA, 1977.

54. Birch, T.W.; Powell, D.S. The Forest-Land Owners of Kentucky; Resource Bulletin NE-57; USDA Forest Service, Northeastern Forest Experiment Station: Broomall, PA, USA, 1978.

55. Birch, T.W.; Kingsley, N.P. The Forest-Land Owners of West Virginia; Resource Bulletin NE-58; USDA Forest Service, Northeastern Forest Experiment Station: Broomall, PA, USA, 1978.

56. Kingsley, N.P.; Birch, T.W. The Forest-Land Owners of Maryland; Resource Bulletin NE-63; USDA Forest Service, Northeastern Forest Experiment Station: Broomall, PA, USA, 1980.

57. Birch, T.W.; Dennis, D.F. The Forest-Land Owners of Pennsylvania; Resource Bulletin NE-66; USDA Forest Service, Northeastern Forest Experiment Station: Broomall, PA, USA, 1980.

58. Birch, T.W.; Lewis, D.G.; Kaiser, H.F. The Private Forest-Land Owners of the United States; Resource Bulletin WO-1; USDA Forest Service: Washington, DC, USA, 1982.

59. Birch, T.W. The Forest-Land Owners of Ohio, 1979; Resource Bulletin NE-74; USDA Forest Service, Northeastern Forest Experiment Station: Broomall, PA, USA, 1982.

60. Birch, T.W. The Forest-Land Owners of New York; Resource Bulletin NE-78; USDA Forest Service, Northeastern Forest Experiment Station: Broomall, PA, USA, 1983.

61. Carpenter, E.M.; Hansen, M.H. The Private Forest Landowners of Michigan; Resource Bulletin NC-93; USDA Forest Service, North Central Forest Experiment Station: St. Paul, MN, USA, 1985. 
62. Carpenter, E.M.; Hansen, M.H. St. John, D.M. The Private Forest Landowners of Minnesota-1982; Resource Bulletin NC-95; USDA Forest Service, North Central Forest Experiment Station: St. Paul, MN, USA, 1986.

63. Birch, T.W. The Forest-Land Owners of Maine, 1982; Resource Bulletin NE-90; USDA Forest Service, Northeastern Forest Experiment Station: Broomall, PA, USA, 1986.

64. Widmann, R.H.; Birch, T.W. Forest-Land Owners of Vermont-1983; Resource Bulletin NE-102; USDA Forest Service, Northeastern Forest Experiment Station: Broomall, PA, USA, 1988.

65. Birch, T.W. Forest-Land Owners of New Hampshire, 1983; Resource Bulletin NE-108; USDA Forest Service, Northeastern Forest Experiment Station: Broomall, PA, USA, 1989.

66. Birch, T.W. Private Forest-Land Owners of the United States, 1994; Resource Bulletin NE-134; USDA Forest Service, Northeastern Forest Experiment Station: Radnor, PA, USA, 1996.

67. Birch, T.W. Private Forest-Land Owners of the Northern United States, 1994; Resource Bulletin 136; USDA Forest Service, Northeastern Forest Experiment Station: Radnor, PA, USA, 1996.

68. Birch, T.W. Private Forest-Land Owners of the Western United States, 1994; Resource Bulletin 137; USDA Forest Service, Northeastern Forest Experiment Station: Radnor, PA, USA, 1996.

69. Birch, T.W. Private Forest-Land Owners of the Southern United States, 1994; Resource Bulletin 138; USDA Forest Service, Northeastern Forest Experiment Station: Radnor, PA, USA, 1996.

70. Leatherberry, E.C.; Kingsley, N.P.; Birch, T.W. Private Timberland Owners of Michigan, 1994; Resource Bulletin NC-191; USDA Forest Service, North Central Forest Experiment Station: St. Paul, MN, USA, 1998.

71. Leatherberry, E.C. Wisconsin's Private Timberland Owners: 1997; Research Paper NC-339; USDA Forest Service, North Central Forest Experiment Station: St. Paul, MN, USA, 2001.

72. Birch, T.W.; Butler, B.J. Private Forest-Land Ownerships of New York: 1980 and 1994; Resource Bulletin NE-153; USDA Forest Service, Northeastern Research Station: Newtown Square, PA, USA, 2001.

73. Rosson, J.F.; Doolittle, L. Profiles of Midsouth Nonindustrial Private Forests and Owners; Resource Bulletin SO-125; USDA Forest Service, Southern Forest Experiment Station: New Orleans, LA, USA, 1987.

74. Cole, A.B.; Smith, R.C. The Forest Resources of Rural Householders in Dent County, Missouri; Research Bulletin 740; Missouri Agricultural Experiment Station: Columbia, MO, USA, 1960.

75. Southern, J.H.; Miller, R.L. Ownership of Land in the Commercial Timber Area of Southeast Texas, 1955; Progress Report 1853; Texas Agricultural Experiment Station: College Station, TX, USA, 1956.

76. Southern, J.H.; Miller, R.L. Ownership of Land in the Commercial Timber Area of Northeast Texas; Progress Report 1903; Texas Agricultural Experiment Station: College Station, TX, USA, 1956.

77. Pennsylvania Cooperative Extension Service; Charmin Paper Products Company. Wyoming County Woodland Owners; Extension Studies No. 39; Pennsylvania State University, College of Agriculture, Extension Service: University Park, PA, USA, 1969.

78. Perry, J.D.; Guttenberg, S. Southwest Arkansas'Small Woodland Owners; Occasional Paper 170; USDA Forest Service, Southern Forest Experiment Station: New Orleans, LA, USA, 1959. 
79. Toms, R.E.; Marlin, C.B. Some Characteristics of Small Landowners in the Pine Region of Northwest Louisiana; LSU Forestry Note No. 102; Louisiana Agricultural Experiment Station: Baton Rouge, LA, USA, 1972.

80. Fontenot, R.W.; Marlin, C.B. Characteristics of Owners of Small Timber Tracts in Southwest Louisiana; LSU Forestry Note No. 106; Louisiana Agricultural Experiment Station: Baton Rouge, LA, USA, 1974.

81. Holemo, F.J.; Brown, E.E. A Profile of the Private, Non-Industrial Forest Landowner in Georgia's Coastal Plain; Georgia Forest Research Paper 82; Georgia Forest Research Council: Macon, GA, USA, 1975.

82. Baumgartner, D.M. Private Nonindustrial Forest Landowners of Okanogan County, Washington; EM 4397; Washington State University, College of Agriculture, Cooperative Extension Service: Pullman, WA, USA, 1978.

83. Koss, W.; Scott, B.D. A Profile of Western Washington's Nonindustrial Forest Landowners; DNR Report No. 37; State of Washington Department of Natural Resources: Olympia, WA, USA, 1978.

84. Jones, J.G.; Thompson, R.P. Characteristic, Attitudes and Objectives of Nonindustrial Private Forest Owners in Eastern Oklahoma; Research Report P-816; Oklahoma Agricultural Experiment Station: Stillwater, OK, USA, 1981.

85. Marsinko, A.; Stevens, H.; Nodine, S. Nonindustrial Private Forest Lands and Landowners in South Carolina; Forest Research Series No. 43; Clemson University, Department of Forestry: Clemson, SC, USA, 1987.

86. Somberg, S.I. Characteristics of Private Nonindustrial Forest Landowners in Alabama; Circular 185; Auburn University Agricultural Experiment Station: Auburn, AL, USA, 1971.

87. White, H.G. Forest ownership research in historical perspective. J. Forest. 1950, 48, 261-264.

88. Chamberlin H.H.; Sample, L.A.; Hayes, R.W. Private Forest Land Ownership and Management in the Loblolly-Shortleaf Type in Southern Arkansas, Northern Louisiana, and Central Mississippi; Louisiana Bulletin No. 393; Louisiana Agricultural Experiment Station: Baton Rouge, LA, USA, 1945.

89. The Management Status of Forest Lands in the United States; Report 3 from a Reappraisal of the Forest Situation; USDA Forest Service: Washington, DC, USA, 1946.

90. Woods, J.B. Report of the Forest Resource Appraisal. Am. For. 1946, 52, 413-428.

91. Yoho, J.G.; James, L.M.; Quinney, D.N. Private Forest Landownership and Management in the Northern Half of Michigan's Lower Peninsula; Technical Bulletin 261; Michigan Agricultural Experiment Station: East Lansing, MI, USA, 1957.

92. Mignery, A.L. Factors affecting small-woodland management in Nacogdoches County, Texas. J. Forest. 1956, 54, 102-105.

93. Tennessee Valley Authority. Influence of Woodland and Owner Characteristics on Forest Management; Report No. 217-56; Tennessee Valley Authority, Division of Forestry Relations: Norris, TN, USA, 1956.

94. Seigworth, K. Economics and ethics. Am. For. 1958, 64, 35-36.

95. Ramke, T.F. TVA management studies. For. Farmer 1960, 20, 30-32. 
96. McDermid, R.W.; Kitt, P.D.; Guttenberg, S. Ownership Factors Affecting Management of Small Woodlands in St. Helena Parish, Louisiana; Bulletin No. 520; Louisiana Agricultural Experiment Station: Baton Rouge, LA, USA, 1959.

97. Gibbs, C.B. Managing a Small Forest in East Texas; Occasional Paper 163; USDA Forest Service, Southern Forest Experiment Station: New Orleans, LA, USA, 1958.

98. Sutherland, C.F., Jr.; Tubbs, C.H. Influence of Ownership on Forestry in Small Woodlands in Central Wisconsin; Station Paper No.77; USDA Forest Experiment Station, Lake States Forest Experiment Station: St. Paul, MN, USA, 1959.

99. Zivnuska, J.A. Private forestry in Norway - A case study in small woodland management and policy. Forest Sci. 1959, Monograph 1, 1-49.

100. Martin, I.R.; McDermid, R.W. Some Viewpoints and Characteristics of Owners of Small Unmanaged Woodlands; LSU Forestry Note No. 42; Louisiana Agricultural Experiment Station: Baton Rouge, LA, USA, 1960.

101. Miller, R.I.; Southern, J.H. Management Intent of Small Timberland Owners in East Texas; MP-439; Texas Agricultural Experiment Station: College Station, TX, USA, 1960.

102. South, D.R.; Hansbrough, T.; Bertrand, A.L. Factors Related to the Adoption of Management Woodland Management Practices; Bulletin No. 603; Louisiana Agricultural Experiment Station: Baton Rouge, LA, USA, 1965.

103. Anderson, W.C. The Small Forest Landowner and His Woodland; Station Paper No. 114; USDA Forest Service, Southeastern Forest Experiment Station: Asheville, NC, USA, 1960.

104. McClay, T.A. Similarities among owners of small private forest properties in nine eastern localities. J. Forest. 1961, 59, 88-92.

105. Keniston, R.F. The forest owner-A person. J. Forest. 1962, 60, 249-254.

106. Mullins, W.H. What about absentee ownership? For. Farmer 1960, 20, 35-37.

107. Quinney, D.N. Small Private Forest Landowners in Michigan's Upper Peninsula -Characteristics, Ownership Attitudes, and Forestry Practices; Station Paper No. 95; USDA Forest Service, Lake States Forest Experiment Station: St. Paul, MN, USA, 1962.

108. Noreen, P.A.; Hughes, J.M. A Study of Absentee Owners of Pine County, Minnesota Forest Land; Minnesota Forestry Research Notes No. 195; School of Forestry, University of Minnesota: Saint Paul, MN, USA, 1968.

109. Holland, I.I.; Beazley, R.I. Independent Factors in Small Woodland Owner Behavior in Illinois; Report F-498; Department of Forestry, University of Illinois: Urbana, IL, USA, 1962.

110. Jones, J.H.; McKean, A.S. A Study of Woodland Management Practices among Small Woodland Owners in Louisiana; Louisiana State University, Agricultural Extension Service: Baton Rouge, LA, USA, 1962.

111. Quinney, D.N. Small private forest landownership in the United States-Individual and social perception. Nat. Resour. J. 1964, 3, 379-393.

112. Christensen, W.W.; Grafton, A.E. Characteristics, Objectives, and Motivations of Woodland Owners in West Virginia; Bulletin 538; West Virginia University Agricultural Experiment Station: Morgantown, WV, USA, 1966. 
113. Munger, J.A.; Loomer, C.W. Ownership and Use of Land for Forestry and Recreation in Northern Wisconsin; Research Bulletin 248; Wisconsin Agricultural Experiment Station: Madison, WI, USA, 1964.

114. Anderson, W.C. Factors Influencing North Carolina's Landowners to Practice Forestry; Research Paper SO-33; USDA Forest Service, Southern Forest Experiment Station: New Orleans, LA, USA, 1968.

115. Schallau, C.H. Forest Owners and Timber Management in Michigan; Research Paper LS-9; USDA Forest Service, Lake States Forest Experiment Station: St. Paul, MN, USA, 1964.

116. Urquhart, B. Special problems of small woods. In Proceedings of the Fifth World Forestry Congress, Seattle, WA, USA, 29 August-10 September 1960; USDA Forest Service: Washington, DC, USA, 1962; pp. 1172-1174.

117. Stoltenberg, C.H.; Gottsacker, J.H. Forest owner attitudes toward forestry. Iowa State J. Sci. 1967, 42, 83-87.

118. Plair, T.B. Opportunities in small woodlands. For. Farmer 1962, 21, 8-9,15-17,19.

119. Preston, J.F. Is farm forestry on the wrong trail? Am. For. 1956, 62, 8-11, 50-52.

120. Quinney, D.N. The "farm woodlot" revisited. J. Forest. 1961, 59, 601-602.

121. Yoho, J.G. Small woodland owners. What is the problem? In 1962 Pulpwood Annual; American Pulpwood Association: Washington, DC, USA; pp. 89-91.

122. Clawson, M. Nonindustrial private forest lands: Myths and realities. In Proceedings of Joint Convention of the Society of American Foresters and Canadian Institute of Forestry, St Louis, MO, USA, 22-26 October 1978; Society of American Foresters: Washington, DC, USA; pp. 208-210.

123. Kaiser, F.; Birch, T.; Lewis, D. New findings on private forest landowners. Am. For. 1982, 88, 28-30, 44.

124. Gould Jr., E.M. WANTED: High-satisfaction forestry. J. Forest. 1978, 76, 715-718.

125. Glasscock, H.R., Jr. Greater outputs from NIPFs: What programs are cost-effective? J. Forest. 1978, 76, 268, 299, 310-312.

126. Brock, S.M. Woodland Owner Attitudes toward Practicing Forestry and Participating in Forestry Associations; Research Series 5; West Virginia University, Office of Research and Development, Appalachian Center: Morgantown, WV, USA, 1968.

127. Bradford, L.E.; Marlin, C.B. Knowledge of Forestry Concepts Compared with Adoption of Forest Practices in Two Louisiana Parishes; LSU Forestry Note 98; Louisiana Agricultural Experiment Station: Baton Rouge, LA, USA, 1972.

128. Le Ray, N.L.; Frick, G.E. Northern New Hampshire Nonindustrial Resident Forest Landowners; Extension Publication No. 8; University of New Hampshire, Cooperative Extension Service: Durham, NH, USA, 1972.

129. New England Research, Inc. Landowner Attitudes and Forest Land Use in Northeastern Connecticut; State of Connecticut, Department of Environmental Protection: Hartford, CT, USA, 1974.

130. Carothers, J.E.; Smith, H.C. Land Use Pattern on Private Forested Properties in Louisiana; Bulletin No. 10; Louisiana Tech University School of Forestry: Ruston, LA, USA, 1977. 
131. Holmes, T.; Diamond, J. An Analysis of Non-Industrial Private Woodland Owners'Attitudes towards Timber Harvesting and Forest Land Use Windham County, Connecticut, 1979; Research Report 63; Storrs Agricultural Experiment Station: Storrs, CT, USA, 1980.

132. Hickman, C.A. Socio-Economic Characteristics of Prospective Nonindustrial Timber Sellers in East Texas; Research Note SO-308; USDA Forest Service, Southern Forest Experiment Station: New Orleans, LA, USA, 1984.

133. Baird, A.W.; Doolittle, L.D.; Burroughs, R.G. Harvesting Decisions of Nonindustrial Private Forest Owners in Mississippi; Sociology Research Report Series 86-2; Department of Sociology and Anthropology, Mississippi State University: Mississippi State, MS, USA, 1986.

134. Marlin, C.B. A Study of Small Owners of Small Timber Tracts in Louisiana; Bulletin No. 710; Louisiana Experiment Station: Baton Rouge, LA, USA, 1978.

135. Porterfield, R.L.; Moak, J.E. Timber management for nonindustrial forest owners: A matter of perspective. South. J. Appl. Forest. 1977, 1, 2-6.

136. Young, R.A.; Reichenbach, M.R. Factors influencing the timber harvest intentions of nonindustrial private forest owners. Forest Sci. 1987, 33, 381-393.

137. Romm, J.; Tuazon, R.; Washburn, C. Relating forestry investment to the characteristics of nonindustrial private forestland owners in Northern California. Forest Sci. 1987, 33, 197-209.

138. Royer, J. Determinants of reforestation behavior among Southern landowners. Forest Sci. 1987, $33,654-667$.

139. Hyberg, B.T.; Holthausen, D.M. The behavior of nonindustrial forest landowners. Can. J. Forest. Res. 1989, 19, 1014-1023.

140. Bliss, J.C.; Martin, A.J. Identifying NIPF management motivations with qualitative methods. Forest Sci. 1989, 35, 601-622.

141. Amacher, G.S.; Conway, M.C.; Sullivan, J. Econometric analysis of nonindustrial forest landowners: Is there anything left to study? J. Forest Econ. 2003, 9, 137-164.

142. Arano, K.G.; Munn, I.A. Evaluating forest management intensity: A comparison among major forest landowner types. Forest. Pol. Econ. 2006, 9, 237-248.

143. Zivnuska, J.A. Two studies of private nonindustrial forestland-A critical review. J. Forest. 1978, 76, 467-469.

144. Royer, J. Conclusions from a review of 50 years of small woodland owner studies. In Proceedings of Southern Forest Economics Workshop, Chapel Hill, NC, USA, 21-22 March 1979; Southern Forest Economics Workers (SOFEW): Department of Forestry, Mississippi State University, Mississippi State, MS, USA, 1980; p.14.

145. Karsen, D.N.; Ganser, D.A. Pennsylvania's Private Woodland Owners-A Study of the Characteristics, Attitudes, and Actions of an Important Group of Decision-Makers; Research Paper NE-219; USDA Forest Service, Northeastern Forest Experiment Station: Upper Darby, PA, USA, 1972.

146. Straka, T.J.; Kilgore, M.A.; Jacobson, M.G.; Greene, J.L.; Daniels, S.E. Influence of financial incentives programs in sustaining wildlife values. Hum. Dimens. Wildl. 2007, 31, 23-27. 
147. Bengston, D.N.; Asah, S.T.; Butler, B.J. The diverse values and motivations of family forest owners in the United States: An analysis of an open-ended question in the national woodland owner survey. Small-Scale Forest. 2011, 10, 339-355.

148. Brunson, M.W.; Yarrow, D.T.; Roberts, S.D.; Guynn, D.C., Jr.; Kuhns, M.R. Nonindustrial private forest owners and ecosystem management: Can they work together? J. Forest. 1996, 94, 14-21.

149. Rasamoelina, M.S.; Johnson, J.E.; Hull, R.B. Adoption of woodland management practices by private forest owners in Virginia. Forest Sci. 2010, 56, 444-452.

150. Conway, M.C.; Amacher, G.S.; Sullivan, J.; Wear, D. Decisions nonindustrial forest landowners make: An empirical examination. J. Forest Econ. 2003, 9, 181-203.

151. Joshi, S.; Arano, K.G. Determinants of private forest management decisions: A study on West Virginia NIPF landowners. For. Pol. Econ. 2009, 11, 118-125.

152. Straka, T.J. Recognition of wildlife amenity values in defining the small forest ownership problem in the United States-A literature review. Wildl. Biol. Pract. 2011, 7, 1-22.

153. Belin, D.L.; Kittredge, D.B.; Stevens, T.H.; Dennis, D.C.; Schweik, C.M.; Morzuch, B.J. Assessing private forest owner attitudes toward ecosystem-based management. J. Forest. 2005, 103, 28-35.

154. Finley, A.O.; Kittredge Jr. D.B. Thoreau, Muir, and Jane Doe: Different types of private forest owners need different kinds of forest management. North. J. Appl. Forest. 2006, 23, 27-34.

155. Bliss, J.C.; Martin, A.J. Identity and private forest management. Soc. Nat. Resour. 1988, 1, 365-376.

156. Moser, W.K.; Leatherberry, E.C.; Hansen, M.H.; Butler, B.J. Farmers' objectives toward their woodlands in the Upper Midwest of the United States: Implications for woodland volumes and diversity. Agrofor. Syst. 2009, 75, 49-60.

157. Potter-Witter, K. A cross-sectional analysis of Michigan nonindustrial private forest landowners. North. J. Appl. Forest. 2005, 22, 132-138.

158. Bliss, J.C. Sustaining family forests in rural landscapes: Rationale, challenges and an illustration from Oregon, USA. Small-Scale For. Econ. Manag. Pol. 2003, 2, 1-8.

159. Force, J.E.; Lee, H.W. Nonindustrial private forest owners in Idaho. West. J. Appl. Forest. 1991, 6, 32-36.

160. Hasel, A.A.; Poli, A. A new approach to forest ownership surveys. Land Econ. 1949, 25, 1-10.

161. Poli, A. Conducting a survey of ownership of forest land in California. Agric. Econ. Res. 1952, 4, 8-12.

162. Duerr, W.A.; Vaux, H.J.; Stoddard, C.H. Some Research needs in the Economics of Forestry. In Proceedings of Society of American Foresters Meeting, Milwaukee, WI, USA, 24-27 October 1954; Society of American Foresters: Washington, DC, USA, 1955; pp. 161-162.

163. Webster, H.H. Economic research for more effective assistance to woodland owners. Land Econ. 1964, 40, 371-380.

164. Alig, R.J. Modeling Acreage Changes in Forest Ownerships and Cover Types in the Southeast; Research Paper RM-260; USDA Forest Service, Rocky Mountain Forest and Range Experiment Station: Fort Collins, CO, USA, 1985. 
165. Nonindustrial Private Forests: Data and Information Needs Conference Proceedings, Durham, NC, USA, 17-18 April 1980; Royer, J.P., Convery, F.J., Eds.; Duke University School of Forestry and Environmental Studies: Durham, NC, USA, 1981.

166. Butler, B.J.; Leatherberry, E.C.; Williams, M.S. Design, Implementation, and Analysis Methods for the National Woodland Owner Survey; General Technical Report NE-336; USDA Forest Service, Northeastern Research Station: Newtown Square, PA, USA, 2005.

167. Nelson, A.Z. Multiple-purpose forest management. In Research in the Economics of Forestry; Duerr, W.A., Vaux, H.J., Eds.; The Waverly Press: Baltimore, MD, USA, 1953; pp. 255-263.

168. Binkley, C.S. Timber Supply from Private Nonindustrial Forests: A Microeconomic Analysis of Landowner Behavior; Bulletin No. 92; Yale University School of Forestry and Environmental Studies: New Haven, CT, USA, 1981.

169. Kendra, A.; Hull, R.B. Motivations and behaviors of new forest owners in Virginia. Forest Sci. 2005, 51, 142-154.

170. Davis, M.L.E.S.; Fly, J.M. Do you hear what I hear: Better understanding how forest management is conceptualized and practiced by private forest landowners? J. Forest. 2010, 108, 321-328.

171. Stoddard, C.H. The Small Private Forest in the United States; Resources for the Future, Inc.: Washington, DC, USA, 1961.

172. Kingsley, N.P. How important is timber production to small owners? For. Farmer 1979, 38, $8,9,14,15$.

173. Turner, B.J.; Finley, J.C.; Kingsley, N.P. How reliable are woodland owners' intentions? J. Forest. 1977, 75, 498-499.

174. Streyffert, T. Influence of Ownership and Size Structure on Forest Management in Sweden: A Study of Fundamentals; Bulletin No. 23b; Royal School Of Forestry: Stockholm, Sweden, 1957.

175. Streyffert, T. Management of small woodlots in Sweden. Am. For. 1961, 67, 16-19,52,54,57-58.

176. Koehler, W. Small farm forests in Northern Germany. Am. For. 1959, 65, 37-38,50-53.

177. Yoho, J.G. An American view of the Swedish experience. Am. For. 1961, 67, 34-35,44-49.

178. Kittredge, D.B. The cooperation of private forest owners on scales larger than one individual property: International examples and potential application in the United States. Forest. Pol. Econ. 2005, 7, 671-688.

179. Bieling, C. Non-industrial private-forest owners: Possibilities for increasing adoption of cost-to-nature forest management. Eur. J. Forest. Res. 2004, 123, 293-303.

180. Boon, T.E.; Meilby, H.; Thorsen, B.J. An empirically based typology of private forest owners in Denmark: Improving communication between authorities and owners. Scand. J. Forest. Res. 2004, 19, 45-55.

181. Kvarda, M.E. 'Non-agricultural forest owners' in Austria-A new type of forest ownership. Forest. Pol. Econ. 2004, 6, 459-467.

182. Novais, A.; Canadas, M. Understanding the management logic of private forest owners: A new approach. Forest. Pol. Econ. 2010, 12, 173-180.

183. Swingler, W.S. Improving small woodlands in the United States. Unasylva 1959, 13, 66-76.

184. James, L.M. Farm woodlands and timber economy of Michigan. Mich. Q. Bull. 1960, 42, 563-583. 
185. Mullaney, G.E.; Robinson, V.L. Forest Investment by Non-Industrial Private Landowners in Georgia; Georgia Forest Research Paper 12; Georgia Forestry Commission: Macon, GA, USA, 1980.

186. Butler, B.J.; Leatherberry, E.C. America's family forest owners. J. Forest. 2004, 102, 4-9.

187. Cleaves, D.A.; Bennett, M. Holding size and behavior of nonindustrial private landowners: A cautious second look. In Proceedings of Southern Forest Economics Workshop, Savannah, GA, USA, 27-29 March 1994; Southern Forest Economics Workers (SOFEW): Department of Forestry, Mississippi State University, Mississippi State, MS, USA, 1995; pp. 196-209.

188. Vokoun, M.; Amacher, G.S.; Wear, D.N. Scale of harvesting by non-industrial private forest landowners. J. Forest. Econ 2006, 11, 223-244.

189. Mills Jr., W.L.; Hoover, W.L.; Vasan, S.; McNamara, K.T.; Nagubadi, V. Factors influencing participation in public management assistance programs. In Proceedings of the Symposium on Non-Industrial Private Forests: Learning from the Past, Prospects for the Future, Washington, DC, USA, 18-20 February 1996; Baughman, M.J., Ed.; University of Minnesota Extension Services Special Programs: St. Paul, MN, USA, 1996; pp. 204-213.

190. Hyberg, B.T.; Holthausen, D.M. The behavior of nonindustrial private forest landowners. Can. J. Forest. Res. 1989, 19, 1014-1023.

191. Karppinen, H. Values and objectives of non-industrial private forest owners in Finland. Silva Fenn. 1998, 32, 43-59.

192. Pan, Y.; Zhang, Y.; Butler, B.J. Trends among family forest owners in Alabama, 1994-2004. South. J. Appl. Forest. 2007, 31, 117-123.

193. Cleaves, D.A.; Bennett, M. Timber harvesting by nonindustrial private forest landowners in Western Oregon. West. J. Appl. Forest. 1995, 10, 66-71.

194. Kurttila, M.; Hämäläinen, K.; Kajanus, M.; Pesonen, M. Non-industrial private forest owners' attitudes towards the operational environment of forestry-A multinominal logit model analysis. Forest. Pol. Econ. 2001, 2, 13-28.

195. Stoddard, C.H. Needed: A research program in forest owner education. J. Forest. 1950, 48, 339-341.

196. Butler, B.J.; Tyrell, M.; Feinberg, G.; VanManen, S.; Wiseman, L.; Wallinger, S. Understanding and reaching family forest owners: Lessons from social marketing research. J. Forest. 2007, 105, 348-357.

197. Kittredge, D.B. Extension/outreach implications for America's family forest owners. J. Forest. 2004, 102, 15-18.

198. Kilgore, M.A.; Snyder, S.A.; Schertz, J.; Taff, S.J. What does it take to get family forest owners to enroll in a forest stewardship-type program? Forest. Pol. Econ. 2008, 10, 507-514.

199. Wilson, R.K. Collaboration in context: Rural change and community forestry in the Four Corners. Soc. Nat. Resour. 2006, 19, 53-70.

200. Egan, A.; Jones, S. Do landowner practices reflect beliefs? Implications of an extension-research partnership. J. Forest. 1993, 91, 39-45.

201. Measells, M.K.; Grado, S.C.; Hughes, H.G.; Dunn, M.A.; Idassi, J.; Zielinske, B. Nonindustrial private forest landowner characteristics and use of forestry services in four southern states: Results from a 2002-2003 mail survey. South. J. Appl. Forest. 2005, 29, 194-199. 
202. Rickenbach, M.G.; Guries, R.P.; Schmoldt, D.J. Membership matters: Comparing members and non-members of NIPF owner organizations in Southwest Wisconsin, USA. Forest. Pol. Econ. 2006, 8, 93-103.

203. Cubbage, F.W.; New, B.D.; Moulton, R.J. Evaluations of technical assistance programs for nonindustrial private forest landowners. In Proceedings of Symposium Nonindustrial Private Forests: Learning from the Past, Prospects for the Future, Washington, DC, USA, 18-20 February 1996; Baughman, M.A., Goodman, N., Eds.; University of Minnesota Extension Service: Saint Paul, MN, USA, 1996; pp. 367-376.

204. Society of American Foresters. Improving Outputs from Nonindustrial Private Forests; Study Report of a Task Force; Society of American Foresters: Washington, DC, USA, 1979.

205. Anderson, W.C. Technical Assistance by a County Forester to Nonindustrial Forest Owners in Mississippi; Research Paper SO-239; USDA Forest Service, Southern Forest Experiment Station: New Orleans, LA, USA, 1987.

206. Schuster, E.G. Evaluating Nonindustrial Private Landowners for Forestry Assistance Programs: A Logistic Regression Approach; Research Paper INT-320; USDA Forest Service, Intermountain Forest and Range Experiment Station: Ogden, UT, USA, 1983.

207. Cubbage, F.W.; Skinner, T.M. Risbrudt, C.D. An Economic Evaluation of the Georgia Rural Forestry Assistance Program; Research Bulletin 322; University of Georgia College of Agriculture Experiments Stations: Athens, GA, USA, 1985.

208. Skinner, T.M.; Cubbage, F.W. A Survey of Industrial Forest Management Assistance and Leasing Programs for Nonindustrial Private Forests in Georgia; Research Report 470; University of Georgia College of Agriculture Experiment Stations: Athens, GA, USA, 1985.

209. Carpenter, E.M. Ownership Change and Timber Supply on Nonindustrial Private Forest Land; Research Paper NC-265; USDA Forest Service, North Central Experiment Station: St. Paul, MN, USA, 1985.

210. Callahan, J.C.; Lauderdale, K.R. Integrative and other economic aspects of tree farm families. J. Forest. 1964, 62, 550-555.

211. Clepper, H. Tree farming in America. Unasylva 1967, 21, 2-8.

212. Canham, H.O. Forest Ownership and Timber Supply; State University of New York, College of Environmental Science and Forestry: Syracuse, NY, USA, 1973.

213. Majumdar, I.; Laband, D.; Teeter, L.; Butler, B. Motivations and land-use intentions of nonindustrial private forest landowners: Comparing inheritors to noninheritors. Forest Sci. 2009, 55, 423-432.

214. Majumdar, I.; Teeter, L.; Butler, B. Characterizing family forest owners: A cluster analysis approach. Forest Sci. 2008, 54, 176-184.

215. Majumdar, I.; Teeter, L.D.; Butler, B.J. Using extant data to determine management direction in family forests. Soc. Nat. Resour. 2009, 22, 867-883.

216. Sample, V.A.; Mater, C.; Butler, B. The new generation of private forest landowners: Brace for change. Pinchot Lett. 2005, 10, 1-4.

217. Gan, J.; Kolison, S.H., Jr.; Tackie, N.O. African-American forestland owners in Alabama's black belt. J. Forest. 2003, 101, 38-43. 
218. Gan, J.; Kolison, S.H., Jr. Minority forestland owners in Southeastern Alabama. South. J. Appl. Forest. 1999, 23, 175-178.

219. Skok, R.A.; Gregersen, H.M. Motivating private forestry: An overview. J. Forest. 1975, 73, 202-205.

220. Worrell, A.C.; Irland, L.C. Alternative means of motivating investment in private forestry. $J$. Forest. 1975, 73, 206-209.

221. Barrett, L.I. How to achieve better management on small woodlands. In Proceedings of the Fifth World Forestry Congress, Seattle, WA, USA, 29 August-10 September 1960; USDA Forest Service: Washington, DC, USA, 1962; pp. 1137-1150.

222. National Association of State Foresters. In Proceedings of the National Private Non-Industrial Forestry Conference; General Technical Report WO-22; USDA Forest Service: Washington, DC, USA, 1980.

223. Amacher, G.S.; Sullivan, J.; Shabman, L.; Zepp, L.; Grebner, D. Reforestation of flooded farmland: Policy implications from the Mississippi River Delta. J. Forest. 1998, 96, 10-17.

224. Gould, E.M., Jr. The search for parity. J. Forest. 1975, 73, 217-221.

225. Schaaf, K.A.; Broussard, S.R. Private forest policy tools: A national survey exploring the American public's perceptions and support. Forest. Pol. Econ. 2006, 9, 316-334.

226. Doolittle, M.L.; Straka, T.J. Regeneration following harvest on nonindustrial private pine sites in the South: A diffusion of innovations perspective. South. J. Appl. Forest. 1987, 11, 37-41.

227. Arano, K.G.; Munn, I.A.; Gunter, J.E.; Bullard, S.H.; Doolittle, M.L. Comparison between regenerators and non-regenerators in Mississippi: A discriminant analysis. South. J. Appl. Forest. 2004, 28, 189-195.

228. Howle, M.B.; Straka, T.J.; Nespeca, M.C. Family forest owners' perceptions on chemical methods for invasive species control. Invasive Plant Sci. Manag. 2010, 3, 253-261.

229. Jacobson, M.; Jones, E.; Cubbage, F. Landowner attitudes toward landscape-level management. In Proceedings of Symposium Nonindustrial Private Forests: Learning from the Past, Prospects for the Future, Washington, DC, USA, 18-20 February 1996; Baughman, M.A., Goodman, N., Eds.; University of Minnesota Extension Service: St. Paul, MN, USA, 1996; pp. 417-425.

230. Sun, X.; Munn, I.A.; Sun, C.; Hussain, A. How promptly nonindustrial private forest landowners regenerate their lands after harvest: A duration analysis. Can. J. Forest. Res. 2008, 38, 2109-2117.

231. Duerr, W.A. Timber supply: Goals, prospects, problems. Am. J. Agric. Econ. 1974, 56, 927-935.

232. Kuuluvainen, J.; Karppinen, H.; Ovaskainen, V. Landowner objectives and nonindustrial private timber supply. Forest Sci. 1996, 42, 300-309.

232. USDA Forest Service. An Analysis of the Timber Situation in the United States, 1952-2030; Forest Resource Report No. 23; USDA Forest Service: Washington, DC, USA, 1982.

234. Smith, W.B.; Miles, P.D.; Perry, C.H.; Pugh, S.A. Forest Resources of the United States, 2007; General Technical Report WO-78; USDA Forest Service: Washington, DC, USA, 2009.

235. Oswalt, S.N., Thompson, M., Smith, W.B., Eds.; U.S. Forest Resource Facts and Historical Trends; FS-801; USDA Forest Service: Washington, DC, USA, 2009.

236. Row, C. Economies of tract size in timber growing. J. Forest. 1978, 76, 576-579.

237. Clawson, M. Economic size of forestry operations. J. Forest. 1957, 55, 521-526. 
238. Cubbage, F.W. Economics of Forest Tract Size: Theory and Literature; General Technical Report SO-41; USDA Forest Service, Southern Forest Experiment Station: New Orleans, LA, USA, 1983.

239. Cubbage, F.W. Economies of Forest Tract Size in Southern Pine Harvesting; Research Paper SO-184; USDA Forest Service, Southern Forest Experiment Station: New Orleans, LA, USA, 1982.

240. Karppinen, H. Forest owners' choice of reforestation method: An application of the theory of planned behavior. Forest. Pol. Econ. 2005, 7, 393-409.

241. Wiersum, K.F.; Elands, B.H.; Marjanke, A.H. Small-scale forest ownership across Europe: Characteristics and future potential. Small-Scale Forest. 2005, 4, 1-19.

242. Bliss, J.C.; Kelly, E.C. Comparative advantage of small-scale forestry among emerging forest tenures. Small-Scale Forest. 2008, 7, 95-104.

243. Zhang, Y.; Liao, X.; Butler, B.J.; Schelhas, J. The increasing importance of small-scale forestry: Evidence from family forest ownership patterns in the United States. Small-Scale Forest. 2009, $8,1-14$.

244. Fecso, R.S.; Kaiser, H.F.; Royer, J.P.; Weidenhamer, M. Management Practices and Reforestation Decisions for Harvested Southern Pinelands; SRS Staff Report Number AGES821230; USDA Statistical Reporting Service: Washington, DC, USA, 1982.

245. Gunter, J.E. 'Intermediate technology' key to small woodlands productivity. For. Ind. 1979, 106, 64-66, 70.

246. Knight, H.A. Size of Timber Stands in the Piedmont of South Carolina; Research Note SE-267; USDA Forest Service, Southeastern Forest Experiment Station: Asheville, NC, USA, 1978.

247. Thompson, R.P.; Jones, J.G. Classifying nonindustrial private forestland by tract size. J. Forest. 1981, 79, 288-291.

248. Haines, A.L.; Kennedy, T.T.; McFarlane, D.L. Parcelization: Forest change agent in Northern Wisconsin. J. Forest. 2011, 109, 101-108.

249. Mehmood, S.R.; Zhang, D. Forest parcelization in the United States: A study of contributing factors. J. Forest. 2001, 99, 30-34.

250. Sampson, N.; DeCoster, L. Forest fragmentation: Implications for sustainable forests. J. Forest. 2000, 98, 4-8.

251. Best, C. America's private forests: Challenges for conservation. J. Forest. 2002, 100, 14-17.

252. Germain, R.H.; Anderson, N.; Berilacqua, E. The effects of forestland parcelization and ownership transfers on nonindustrial private forestland forest stocking in New York. J. Forest. 2007, 105, 403-408.

253. DeCoster, L.A. The boom in forest owners-A bust for forestry? J. Forest. 1998, 96, 25-28.

254. Moldenhauer, M.C.; Bolding, M.C. Parcelization of South Carolina's private forestland: Loggers reactions to a growing threat. For. Prod. J. 2009, 59, 37-43.

255. Schallau, C.H. Small Forest Ownership in the Urban Fringe Area of Michigan; Station Paper No. 103; USDA Forest Service, Lake States Forest Experiment Station: St. Paul, MN, USA, 1962. 
256. Schallau, C.H. Fragmentation, Absentee Ownership, and Turnover of Forest Land in Northern Lower Michigan; Research Paper LS-17; USDA Forest Service, Lake States Forest Experiment Station: St. Paul, MN, USA, 1965.

257. Human Influences on Forest Ecosystems: The Southern Wildland-Urban Interface Assessment; General Technical Report SRS-55; Macie, E.A., Hermansen, L.A., Eds.; USDA Forest Service, Southern Research Station: Asheville, NC, USA, 2002.

258. Stone, R.N. A Comparison of Woodland Owner Intent with Woodland Practice in Michigan's Upper Peninsula. Ph.D. Dissertation, University of Minnesota: St. Paul, MN, USA, 1970.

259. Egan, A.F.; Jones, S.B. Field note: The reliability of landowner survey responses to questions on forest ownership and harvesting. North. J. Appl. Forest. 1995, 12, 184-186.

260. Blatner, K.A.; Greene, J.L. Woodland owner attitudes toward timber production and management. Resource Manag. Optim. 1989, 6, 205-223.

261. Kurtz, W.B.; Lewis, B.J. Decision-making framework for nonindustrial private forest owners: An application in the Missouri Ozarks. J. Forest. 1981, 79, 285-288.

262. Larsen, D.; Gasner, D. Explaining the Forest Products Selling Behavior of Private Woodland Owners; Research Paper NE-257; USDA Forest Service, Northeastern Forest Experiment Station: Upper Darby, PA, USA, 1973.

263. Taylor, F.E.; Wilkerson, C.G. Profile of participants in landowner assistance program, Southeastern Mississippi. J. Forest. 1977, 75, 778-779.

264. Young, R.A.; Reichenbach, M.R.; Perkuhn, F.H. PNIF management: A social-psychological study of owners in Illinois. North. J. Appl. For. 1985, 2, 91-94.

265. Beazley, R.I.; Holland, I.I. Predicting the Success of Alterative Government Incentive Programs: A Case Analysis of Small Woodland Owner Behavior; Monographs Sciences Series Number 3; Southern Illinois University: Carbondale, IL, USA, 1973.

266. Wheatcraft, A.M. Public Assistance Programs for Nonindustrial Private Forestry: An Annotated Bibliography; Staff Paper Series NO. 26, Paper No. 1818; University of Minnesota Agricultural Experiment Station: St. Paul, MN, USA, 1982.

267. Bliss, J.C.; Martin, A.J. How tree farmers view management incentives. J. Forest. 1990, 88, 23-29, 42 .

268. Boyd, R. Government support of nonindustrial production: The case of private forests. South. Econ. J. 1984, 51, 88-107.

269. Cubbage, F.W. The public interest in private forests: Developing regulations and incentives. In Creating a Forestry for the 21st Century: The Science of Ecosystem Management; Kohm, K.A., Franklin, J.F., Eds.; Island Press: Washington, DC, USA; pp. 337-356.

270. Hutton, J.M.; Leader-Williams, N. Sustainable use and incentive-driven conservation: Realigning human and conservation interests. Oryx 2003, 37, 215-226.

271. Lee, K.J.; Kaiser, H.F.; Alig, R.J. Substitution of public and private finding in planting of southern pine. South. J. Appl. Forest. 1992, 16, 204-208.

272. Royer, J.P. Reforestation tax incentives and cost-sharing in North Carolina: A question of efficiency. J. Soil Water Conserv. 1987, 42, 191-193.

273. Straka, T.J.; Greene, J.L. Reforestation tax incentives under the American Jobs Creation Act of 2004. South. J. Appl. Forest. 2007, 31, 23-27. 
274. Rossi, F.J.; Carter, D.R.; Alavalapati, J.R.R.; Nowak, J.T. Forest landowner participation in stateadministered southern pine beetle prevention cost-share programs. South. J. Appl. Forest. 2010, 34, 110-117.

275. Ross-Davis, A.L.; Broussard, S.R.; Jacobs, D.F.; Davis, A.S. Afforestation motivation of private landowners: An examination of hardwood tree plantings in Indiana. North. J. Appl. Forest. 2005, 22, 149-153.

276. Yoho, J.G.; James, L.M. Influence of some public assistance programs on forest landowners in Northern Michigan. Land Econ. 1958, 34, 357-364.

277. Webster, H.H.; Stoltenberg, C.H. What ownership characteristics are useful in predicting response to forestry programs? Land Econ. 1959, 35, 292-295.

278. James, L.M.; Schallau, C.H. Forestry practices under the Agricultural Conservation Program. Land Econ. 1961, 37, 142-149.

279. Muench, J. Private Forests and Public Programs in North Carolina; North Carolina Forestry Association: Raleigh, NC, USA, 1965.

280. Cloud, M.C. Promoting forest management with owners of medium-sized parcels of land. J. Forest. 1966, 64, 536-537.

281. Bullard, S.H.; Straka. T.J. Structure and funding of state-level forestry cost-share programs. North. J. Appl. Forest. 1988, 5, 132-135.

282. McKillop, W. Social benefits of forestry incentive programs. J. Forest. 1975, 73, 214-216.

283. Mills, T.J.; Cain, D. 1974 Forestry Incentives Program: Indicators of cost effectiveness. J. Forest. 1976, 74, 678-683.

284. Mills, T.J. Cost Effectiveness of the 1974 Forestry Incentives Program; Research Paper RM-175; USDA Forest Service, Rocky Mountain Forest and Range Experiment Station: Fort Collins, CO, USA, 1976.

285. Mills, T.J.; Cain, D. Timber Yield and Financial Return Performance of the 1974 Forestry Incentives Program; Research Paper RM-204; USDA Forest Service, Rocky Mountain Forest and Range Experiment Station: Fort Collins, CO, USA, 1978.

286. Mills, T.J.; Cain, D. Financial efficiency of the 1974 Forestry Incentives Program. J. Forest. 1979, 77, 661-666.

287. Dunn, B.A.; Beese, M.J. Structure, Characteristics of Participants and Effectiveness of the Forestry Incentives Program in South Carolina; Forest Research Series No. 31; Clemson University Department of Forestry: Clemson, SC, USA, 1977.

288. Barber, J.C. Impacts of State and Private Programs on Forest Resources and Industries in the South; Forest Resource Report No. 25; USDA Forest Service: Washington, DC, USA, 1989.

289. Henly, R.K.; Ellefson, P.V.; Baughman, M.J. Minnesota's Private Forestry Assistance Program: An Economic Evaluation; Miscellaneous Publication 58-1988; University of Minnesota Agricultural Experiment Station: St. Paul, MN, USA, 1988.

290. Risbrudt, C.D.; Ellefson, P.V. An Economic Evaluation of the 1979 Forestry Incentive Program; Station Bulletin 550-1983; University of Minnesota Agricultural Experiment Station: St. Paul, MN, USA, 1983.

291. Royer, J.P.; Moulton, R.J. Reforestation incentives: Tax incentives and cost sharing in the South. J. Forest. 1987, 85, 45-47. 
292. Kurtz, W.B.; Noweg, T.A.; Moulton, R.J.; Alig, R. An Analysis of the Retention, Condition and Land Use Implications of Tree Plantings Established under the Soil Bank Program, the Forestry Incentives Program and the Agricultural Conservation Program; Station Report 464; University of Missouri Agricultural Experiment Station: Columbia, MO, USA, 1994.

293. Gaddis, D.A.; New, B.D.; Cubbage, F.W.; Abt, R.C.; Moulton, R.J. Accomplishments and Economic Evaluations of the Forestry Incentives Program: A Review; Working Paper No. 78; Southeastern Center for Forest Economics Research: Research Triangle Park, NC, USA, 1995.

294. New, B.D.; Cubbage, F.W.; Moulton, R.J. The Stewardship Incentive Program, 1992-1994: An Accomplishment and Program Review; Working Paper No. 83; Southeastern Center for Forest Economics Research: Research Triangle Park, NC, USA, 1997.

295. Gregersen, H.; Houghtaling, T.; Rubinstein, A. Economics of Pubic Forestry Incentive Programs: A Case Study of Cost-Sharing in Minnesota; Technical Bulletin 315; University of Minnesota Agricultural Experiment Station: St. Paul, MN, USA, 1979.

296. Hickman, C.A. Inconsistent Forest Property Tax Policies within Selected Southern States; Research Paper SO-253; USDA Forest Service, Southern Forest Experiment Station: New Orleans, LA, USA, 1989.

297. Greene, J.L. State tax systems and their effects on nonindustrial private forest owners. In Proceedings of the 194 Society of American Foresters/Canadian Institute of Forestry Convention, Anchorage, AK, USA, 18-22 September 1994; Society of American Foresters: Bethesda, MD, USA, 1995; pp. 414-419.

298. Greene, J.L. The economic effect of federal income tax incentives in southern timber types. In Proceedings of the 1997 Society of American Foresters National Convention, Memphis, TN, USA, 4-9 October 1997; Society of American Foresters: Bethesda, MD, USA, 1998; pp. 231-241.

299. Koontz, M.A.; Hoover, W.L. Tax incentives to promote environmental management by nonindustrial private forest owners. In Proceedings of the 2000 Society of American Foresters National Convention, Washington, DC, USA, 16-20 November 2000; Society of American Foresters: Bethesda, MD, USA, 2001; pp. 128-134.

300. Rodenberg, J.; Jacobson, M.; McDill, M. An evaluation of forest property tax programs in the United States. In Proceedings of 2003 Southern Forest Economics Workshop, New Orleans, LA, USA, 17-18 March 2003; Southern Forest Economics Workers (SOFEW): Mississippi State University, Department of Forestry, Mississippi State, MS, USA, 2004; p. 106.

301. Wicker, G. Motivation for private forest landowners. In Southern Forest Resource Assessment; Technical Report GTR-SRS-53; Wear, D.N., Greis, J.G., Eds.; USDA Forest Service, Southern Research Station: Asheville, NC, USA, 2002; Chapter 9, pp. 225-237.

302. Forest Stewardship Program; USDA Forest Service: Washington, DC, USA, 2011. Available online: http://www.fs.fed.us/spf/coop/programs/loa/fsp.shtml (accessed on 8 July 2011).

303. Gaddis, D.A. Accomplishments and program evaluations of forestry financial assistance programs. In Proceedings of Symposium Nonindustrial Private Forests: Learning from the Past, Prospects for the Future, Washington, DC, USA, 18-20 February 1996; Baughman, M.A., Goodman, N., Eds.; University of Minnesota Extension Service: St. Paul, MN, USA, 1996; pp. 357-366. 
304. Walkingstick, T.; Voth, D.E.; Williams, R.A.; Earl, J.; Hitt, C.P. A characterization of the nonindustrial private forest landowner's of Arkansas. In Proceedings of the Symposium on Arkansas Forests: A Conference on the Results of the Recent Forest Survey of Arkansas, General Technical Report SRS-41; Guldin, J.M., Ed.; USDA Forest Service, Southern Research Station: Asheville, NC, USA, 2001.

305. Graesser, P.W.; Force, J.E. Early and late adopters of stewardship planning. In Proceedings of Symposium Nonindustrial Private Forests: Learning from the Past, Prospects for the Future, Washington, DC, USA, 18-20 February 1996; Baughman, M.A., Goodman, N., Eds.; University of Minnesota Extension Service: St. Paul, MN, USA, 1996; pp. 222-229.

306. Hanson, N. Family-owned forests in an era of regulatory uncertainty. In Proceedings of Symposium Nonindustrial Private Forests: Learning from the Past, Prospects for the Future, Washington, DC, USA, 18-20 February 1996; Baughman, M.A., Goodman, N., Eds.; University of Minnesota Extension Service: St. Paul, MN, USA, 1996; pp. 95-100.

307. Johnson, R.L.; Alig, R.J.; Moore, E.; Moulton, R.J. NIPF landowners' view of regulation. J. Forest. 1997, 95, 23-28.

308. Rickenbach, M.G. Forest certification of small ownerships: Some practical challenges. J. Forest. 2002, 100, 43-47.

309. Kilgore, M.A.; Leahy, J.E.; Hibbard, C.M.; Donnay, J.S. Assessing family forest land certification opportunities: A Minnesota case study. J. Forest. 2007, 105, 27-33.

310. Leahy, J.E.; Kilgore, M.A.; Hibbard, C.M.; Donnay, J.S. Family forest landowners' interest and perceptions of forest certification: Focus group finding from Minnesota. North. J. Appl. Forest. 2008, 25, 73-81.

311. Landowner Assistance Programs; USDA Forest Service: Washington, DC, USA, 2011. Available online: http://www.fs.fed.us/spf/coop/programs/loa/index.shtml (accessed on 8 July 2011).

312. Forestland Enhancement Program; USDA Forest Service: Washington, DC, USA, 2011. Available online: http://www.fs.fed.us/spf/coop/programs/loa/comments_flep.shtml (accessed on 8 July 2011).

313. Wildlife Habitat I incentive Program; USDA Forest Service: Washington, DC, USA, 2011. Available online: http://www.fs.fed.us/spf/coop/programs/loa/whip.shtml (accessed on 8 July 2011).

314. Wildlife Habitat Incentives Program; USDA Natural Resources Conservation Service: Washington, DC, USA, 2011. Available online: http://www.nrcs.usda.gov/Programs/whip (accessed on 8 July 2011).

315. Wetlands Reserve Program; USDA Natural Resources Conservation Service: Washington, DC, USA, 2011. Available online: http://www.nrcs.usda.gov/programs/wrp (accessed on 8 July 2011).

316. Forest Legacy Program; USDA Forest Service: Washington, DC, USA, 2011. Available online: http://www.fs.fed.us/spf/coop/programs/loa/flp.shtml (accessed on 8 July 2011).

317. Environmental Quality Incentives Program; USDA Natural Resource Conservation Service: Washington, DC, USA, 2011. Available online: http:/www.nrcs.usda.gov/PROGRAMS/EQIP (accessed on 8 July 2011). 
318. Conservation Programs; USDA Farm Service Agency: Washington, DC, USA, 2011. Available online: http://www.fsa.usda.gov/FSA/webapp?area=home\&subject=copr\&topic=crp (accessed on 8 July 2011).

319. Conservation Reserve Program; USDA Natural Resources Conservation Service: Washington, DC, USA, 2011. Available online: http://www.nrcs.usda.gov/programs/crp (accessed on 8 July 2011).

320. Esseks, J.D.; Moulton, R.J. Evaluating the Forest Stewardship Program through a National Survey of Participating Forest Land Owners; Northern Illinois University Social Science Research Institute, Center for Governmental Studies: De Kalb, IL, USA, 2000.

321. Bell, C.D.; Roberts, R.K.; English, B.C.; Park, W.M. A logit analysis of participation in Tennessee's Forest Stewardship Program. J. Agr. Appl. Econ. 1994, 26, 463-472.

322. Jennings, B.M.; McGill, D.W. Evaluating the effectiveness of the Forest Stewardship Program in West Virginia: Ten-year assessment. North. J. Appl. Forest. 2005, 22, 236-242.

323. English, B.C.; Bell, C.D.; Wells, G.R.; Roberts, R.K. Stewardship incentives in forestry: Participation factors in Tennessee. South. J. Appl. Forest. 1997, 21, 5-10.

324. Stein, S. Recent USDA Forest Service experiences with forestry incentives: What have we achieved? In Proceedings of Global Initiatives and Policies: First International Conference on Private Forestry in the 21st Century, Atlanta, GA, USA, 25-27 March 2001; Teeter, L., Ed.; Auburn University Forest Policy Center: Auburn, AL, USA, 2001; pp. 112-124.

325. Melfi, F.M.; Straka, T.J.; Marsinko, A.P.; Baumann, J.L. Landowner attitudes toward South Carolina's Forest Stewardship Program. South. J. Appl. Forest. 1997 21, 158-163.

326. Thrift, T.G.; Straka, T.J.; Marsinko, A.P.; Baumann, J.L. Forest resource management plans: Importance of plan components to nonindustrial private forest landowners in South Carolina. South. J. Appl. Forest. 1997, 21, 164-167.

327. Kilgore, M.A.; Greene, J.L.; Jacobson, M.G.; Straka, T.J.; Daniels, S.E. The influence of financial incentive programs in promoting sustainable forestry on the nation's family forests. J. Forest. 2007, 105, 184-191.

328. Jacobson, M.G.; Greene, J.L.; Straka, T.J.; Daniels, S.E.; Kilgore, M.A. Influence and effectiveness of financial incentive programs in promoting sustainable forestry in the South. South. J. Appl. Forest. 2009, 33, 35-41.

329. Jacobson, M.G.; Straka, T.J.; Greene, J.L.; Kilgore, M.A.; Daniels, S.E. Financial incentive programs' influence in promoting sustainable forestry in the northern region. North. J. Appl. Forest. 2009, 26, 61-67.

330. Greene, J.L.; Daniels, S.E.; Kilgore, M.A.; Straka, T.J.; Jacobson, M.G. Effectiveness of financial incentive programs in promoting sustainable forestry in the west. West. J. Appl. Forest. 2010, 25, 186-193.

331. Daniels, S.E.; Kilgore, M.A.; Jacobson, M.G.; Greene, J.L.; Straka, T.J. Examining the compatibility between forestry incentive programs in the US and the practice of sustainable forest management. Forests 2010, 1, 49-64.

332. Gorte, R.W. Forestry in the 2008 Farm Bill; CRS Report for Congress RL33917; Congressional Research Service: Washington, DC, USA, 2008. 
333. Kilgore, M.A.; Blinn, C.R. Policy tools to encourage the application of sustainable timber harvesting practices in the United States and Canada. Forest. Pol. Econ. 2004, 6, 111-127.

334. Bliss, J.C.; Nepal, S.K.; Brooks Jr., R.T.; Larsen, M.D. In the mainstream: Environmental attitudes of Mid-south forest owners. South. J. Appl. Forest. 1997, 21, 37-43.

335. Gan, J.; Kollison, S.H. Minority forest landowners in Southeastern Alabama. South. J. Appl. Forest. 1999, 23, 175-178.

336. Gunter, J.E.; Bullard, S.H.; Doolittle, M.L.; Aranao, K.G. Reforestation of Harvested Timberlands in Mississippi: Behavior and Attitudes of Nonindustrial Private Forest Landowners; Bulletin FO172; Mississippi State University Forestry and Wildlife Research Center: Mississippi State, MS, USA, 2001.

337. Jacobson, M.G. Factors affecting private forest landowner interest in ecosystem management: Linking spatial and survey data. Environ. Manag. 2002, 30, 577-583.

338. Zhang, Y.; Liao, X.; Butler, B.J.; Schelhas, J. The increasing importance of small-scale forestry: Evidence from family forest ownerships in the United States. Small-Scale For. Econ. Manag. Pol. 2009, 8, 1-14.

339. Plantinga, A.J.; Ahn, S.E. Efficient policies for environmental protection: An econometric analysis of incentives for land conversion and retention. J. Agr. Resour. Econ. 2002, 27, 128-145.

340. Greene, J.L.; Blatner, K.A. Identifying woodland owner characteristics associated with timber management. Forest Sci. 1986, 32, 135-146.

341. Measells, M.K.; Grado, S.C.; Hughes, H.G.; Dunn, M.A.; Idassi, J.; Zeilinske, B. Nonindustrial private forest landowner characteristics and use of forestry services in four Southern states: Results from a 2002-2003 mail survey. South. J. Appl. Forest. 2005, 29, 194-199.

342. Baughman, M.J.; Updegraff, K. Landowner Survey of Forest Stewardship Plan Implementation: Final Report; Department of Forest Resources, University of Minnesota: Saint Paul, MN, USA, 2001.

343. Eagan, A.; Gibson, D.; Whipkey, R. Evaluating the effectiveness of the Forest Stewardship Program in West Virginia. J. Forest. 2001, 99, 31-36.

344. Brockett, C.D.; Gerhard, L. NIPF tax incentives: Do they make a difference? J. Forest. 1999, 97 , 16-21.

345. Zhang, D.; Flick, W.A. Carrots, sticks, and reforestation investment. Land Econ. 2001, 77, 443-456.

346. Greene, J.L.; Bullard, S.H.; Cushing, T.L.; Beauvais, T. Effect of the federal estate tax on nonindustrial private forest holdings. J. Forest. 2006, 104, 15-20.

347. Hibbard, C.M.; Kilgore, M.A.; Ellefson, P.V. Property taxation of private forests in the United States: A national review. J. Forest. 2003, 101, 44-49.

348. Hickman, C.A. State property tax and related taxes affecting forest farmer in the South. For. Farm. 1989, 48, 14-16.

349. Bailey, P.D.; Haney, H.L., Jr.; Callihan, D.S.; Greene, J.L. Income tax considerations for forest landowners in the south: A case study on tax planning. J. Forest. 1999, 97, 10-15.

350. Butler, B.J.; Hewes, J.H.; Catanzaro, P.; Greene, J.L.; Kilgore, M.A.; Kittredge, D.B.; Langer, J.; Ma, Z.; Reuben, A.; Tyrrell, M. Effects of Federal, State, and Local Tax Policies on Family Forest Owners: Technical Report; FFRC Research Paper No. 2010-01; USDA Forest 
Service/University of Massachusetts Amherst, Family Forest Research Center: Amherst, MA, USA, 2010.

351. D’Amato, A.W.; Catanzaro, P.F.; Damery, D.T.; Kittredge, D.B.; Ferrare, K.A. Are family forest owners facing a future in which forest management is not enough? J. Forest. 2010, 108, 32-38.

352. Eckhoff, M.; Mackes, K.; Reader, T. Assessing state-sponsored tax incentive programs for nonindustrial private forest landowners in the Western United States. West. J. Appl. Forest. 2007, $22,253-260$.

353. Fortney, J.; Arano, K.G.; Jacobson, M.G. An evaluation of West Virginia's managed timberland tax incentive program. Forest. Pol. Econ. 2011, 13, 69-78.

354. Klosowski, R.; Stevens, T.; Kittredge, D.; Dennis, D. Economic incentives for coordinated management of forestland: A case study of Southern New England. Forest. Pol. Econ. 2001, 2, 29-38.

355. Cloud, M.C. Promotion of forest landowner aggregates. J. Forest. 1969, 67, 868-869.

356. Greene, J.L.; Straka, T.J.; Dee, R.L. Nonindustrial private forest owner use of federal income tax provisions. Forest Prod. J. 2004, 54, 59-66.

357. Kluender, R.A.; Walkingstick, T.L. Rethinking how nonindustrial landowners view their lands. South. J. Appl. Forest. 2000, 24, 150-158.

358. Newman, D.H.; Aronow, M.E.; Harris Jr., T.G.; Macheski, G. Changes in forest land ownership in Georgia. In Proceedings of the Symposium on Non-Industrial Private Forests: Learning from the Past, Prospects for the Future, Washington, DC, USA, 18-20 February 1996; Baughman, M.J., Ed.; University of Minnesota Extension Services Special Programs: St. Paul, MN, USA, 1996; pp. 214-221.

359. Williams, R.A.; Voth, D.E.; Hitt, C. Arkansas' NIPF landowners' opinions and attitudes regarding management and use of forested property. In Proceedings of the Symposium on Non-Industrial Private Forests: Learning from the Past, Prospects for the Future, Washington, DC, USA, 18-20 February 1996; Baughman, M.J., Ed.; University of Minnesota Extension Services Special Programs: St. Paul, MN, USA, 1996: pp. 230-237.

360. Megalos, M.A. North Carolina Landowner Responsiveness to Forestry Incentives. Ph.D. Dissertation, North Carolina State University: Raleigh, NC, USA, 2000.

361. Mehmood, S.R.; Zhang, D. Causes for continuation of state cost-share programs for nonindustrial private forest landowners. Forest Sci. 2003, 48, 471-478.

362. Barraclough, S. A note on "Economic aspects of the farm woodland enterprise". J. Forest Econ. 1957, 39, 783-790.

363. Bethune, J.E.; LeGrande, W.P. Profitable small-forest management-A case history. For. Farmer 1960, 20, 12,13,38.

364. Coutu, A.J. Is forestry financially practical for the small timberland owner? For. Farmer 1960, 20, 8-10,32-33,35.

365. Guttenberg, S. The rate of interest in forest management. J. Forest. 1950, 48, 3-7.

366. Herrick, A.M. Investment aspects of building a forest from bare land. For. Farmer 1960, 20, 14-15,28-30.

367. Redman, J.C. Economic aspects of the farm woodland enterprise. J. Farm Econ. 1956, 38, 901-910. 
368. Wrigley, P.I. Woodland as a Farm Enterprise; Bulletin 536; Pennsylvania State College Agricultural Experiment Station: State College, PA, USA, 1951.

369. Adams, T.C. Marketing of Farm Forest Products. I. Thirteen Western Oregon Counties; Bulletin 567; Oregon Agricultural Experiment Station: Corvallis, OR, USA, 1959.

370. Bolle, A.W. The Timber Industry and the Market for Woodlot Products in the Upper Flathead Valley; Bulletin 160; Montana Forest and Conservation Experiment Station: Missoula, MT, USA, 1960.

371. Bruce, R.W. Marketing Sawlogs and Pulpwood from Small Woodland Holdings; Bulletin 599; Washington Agricultural Experiment Station: Pullman, WA, USA, 1959.

372. Hamilton, L.S. Marketing problems and promotion in the sale of products from small woodlots. For. Chron. 1962, 38, 295-302.

373. Norton, N.A.; Ostrander, M.D.; Rich, J.H. Marketing Forest Products from Small Woodland Areas in the Northeast: II. Buying Practices of Primary Wood-Using Industries and Other First Handlers of Rough Forest Products, III. Use of Marketing Assistance and Information by Forest Products Buyers and Sellers; Bulletin 670; Pennsylvania Agricultural Experiment Station: State College, PA, USA, 1960.

374. Baker, G.; Beyer, F.K. Marketing Forest Products from Small Woodland Areas in Maine; Bulletin 554; Maine Agricultural Experiment Station: Orono, ME, USA, 1956.

375. Preston, J.F. Marketing the products from farm woodlands. J. Forest. 1941, 39, 926-929.

376. Todd, A.S., Jr.; Zirkle, J.J., Jr. Marketing Farm Timber in Monroe County, Georgia; Station Paper No. 3; USDA Forest Service, Southeastern Forest Experiment Station: Asheville, NC, USA, 1949.

377. Casamajor, P.; Teeguarden, D.; Zivnuska, J. Timber Marketing and Land Ownership in Mendocino County; Bulletin 772; California Agricultural Experiment Station: Berkeley, CA, USA, 1960.

378. Teeguarden, D.; Casamajor, P.; Zivnuska, J. Timber Marketing and Land Ownership in the Central Sierra Nevada Region; Bulletin 774; California Agricultural Experiment Station: Berkeley, CA, USA, 1960.

379. Aaltonan A.; Herr, C.S.; Barraclough, K.E. The cooperative marketing of forest products. J. Forest. 1938, 36, 203-215.

380. Cope, J.A. Farm woodland owners' cooperatives. J. Forest. 1943, 41, 169-173.

381. Dempsey, G.P. Forest Cooperatives-A Bibliography; Research Paper NE-82; USDA Forest Service, Northeastern Forest Experiment Station: Broomall, PA, USA, 1967.

382. Dempsey, G.P. Some new guidelines for the forest cooperative. J. Forest. 1968, 66, 17-21.

383. Hawes, A.F. Cooperative Marketing of Woodland Products; Farmers Bulletin 1100; USDA Forest Service: Washington, DC, USA, 1920.

384. Josephson, H.R. Cooperatives-An appraisal of their place in Forestry. For. Farmer 1963, 22, 6-8.

385. Rosen, B.N.; Kaiser, H.F.; Baldeck, M. Nonindustrial private forest landowners as timber marketers: A field study of search for market information and decision quality. Forest Sci. 1989, $35,732-744$.

386. Stoddard, C.H. The need for associations of forest landowners in the United States. J. Forest. 1964, 62, 163-166. 
387. Bennett, F.W.; Grieve, W.G. Aiding small-forest landowners-A cooperative project establishes new consulting foresters at low cost. J. Forest. 1973, 71, 488-490.

388. Solin, L. A Study of Farm Woodland Cooperatives in the United States; Technical Report No. 48; New York State College of Forestry: Syracuse, NY, USA, 1940.

389. Cunningham, R.N. Forest Cooperatives in the United States; Report 6 from A Reappraisal of the Forest Situation; USDA Forest Service: Washington, DC, USA, 1947.

390. Markeson C.B. Identifying the Need for Forestry Associations; Educational Circular 20; USDA Farmer Cooperative Service: Washington, DC, USA, 1965.

391. Robotka, F. Cooperatives in forestry. In Research in the Economics of Forestry; Duerr, W.A., Vaux, H.J., Eds.; The Waverly Press: Baltimore, MD, USA, 1953; pp. 353-359.

392. Simon, D.M.; Scoville, O.J. Forestry Cooperatives: Organization and Performance; ACS Research Report No. 25; USDA Agricultural Cooperative Service: Washington, DC, USA, 1982.

393. Sturgess, E.; Zeuli, K.; Rickenbach, M. A Brief Reflection on Forestry Cooperatives in the US; Bulletin No. 7; University of Wisconsin Center for Cooperatives: Madison, WI, USA, 2004.

394. Hull, R.B.; Ashton, S. Forest cooperatives revisited. J. Forest. 2008, 106, 100-105.

395. Barten, P.K.; Damery, P.; Catanzaro, P; Fish, J; Campbell, S.; Fabos, A.; Fish, L. Massachusetts family forests: Birth of a landowner cooperative. J. Forest. 2001, 99, 23-30.

396. Kittredge, D.B. The cooperation of private forest owners on scales larger than one individual property: International examples and application in the United States. Forest. Pol. Econ. 2005, 7, 671-688.

397. Finley, A.O.; Kittredge, D.B.; Stevens, T.H.; Schweik, C.M.; Dennis, D.C. Interest in cross-boundary cooperation: Identification of distinct types of forest owners. Forest Sci. 2006, $52,10-22$.

398. Frazier, G.D. Small Non-Industrial Forest Owners in Northern Idaho: Their Characteristics, Attitudes, and How They Market Products from Their Woodlands; Bulletin No. 317; Idaho Agricultural Experiment Station: Moscow, ID, USA, 1960.

399. Callahan, J.C.; Fischer, B.C.; Economic and Silvicultural Potentials of 23 Harvested Indiana Woodlands; Station Bulletin 362; Purdue University Agricultural Experiment Station: West Lafayette, IN, USA, 1982.

400. Won, D.J.; Hardie, I.W. An Analysis of Non-Industrial Woodland Owner's Attitudes toward Timber Sales on the Southeastern Shore of Maryland; Miscellaneous Publication 790; Maryland Agricultural Experiment Station: College Park, MD, USA, 1971.

401. Hoover, W.H. Marketing Timber; FNR-1110; Purdue University Cooperative Extension Service: West Lafayette, IN, USA, 2002.

402. US Department of Agriculture. The Federal Role in the Conservation and Management of Private Nonindustrial Forest Lands; Interagency Committee Report; USDA Soil Conservation Service, Forest Service, Extension Service: Washington, DC, USA, 1978.

403. Clawson, M. The Economics of U.S. Nonindustrial Private Forests; Research paper R-14; Resources for the Future: Washington, DC, UDA, 1979.

404. Alig, R.J.; Lee, K.J.; Moulton, R.J. Likelihood of Timber Management on Nonindustrial Private Forests: Evidence from Research Studies; General Technical Report SE-60; USDA Forest Service, Southeastern Forest Experiment Station: Asheville, NC, USA, 1990. 
405. Zhang, Y.; Zhang, D.; Schelhas, J. Small-scale non-industrial private forest ownership in the United States: Rationale and implications for forest management. Silva Fenn. 2005, 39, 443-454.

406. Butler, B.J.; Zhao, M. Family forest owner trends in the Northern United States. North. J. Appl. Forest. 2011, 28, 13-18.

407. Amacher, G.; Conway, C.; Sullivan, J.; Hensyl, C. Effects of Shifting Populations and Preferences on the Behavior of Nonindustrial Landowners and Forest Industry: Empirical Evidence from Virginia; SOFAC Report No. 12; Southern Forest Resource Assessment Consortium: Raleigh, NC, USA, 1998.

408. Hodge, S.S. Challenges for ecosystem management with Virginia NIPF owners. In Proceedings of the Symposium on Non-Industrial Private Forests: Learning from the Past, Prospects for the Future, Washington, DC, USA, 18-20 February 1996; Baughman, M.J., Ed.; University of Minnesota Extension Services Special Programs: St. Paul, MN, USA, 1996; pp. 426-433.

409. Lorenzo, A.B.; Beard, P. Factors affecting the decisions of NIPF owners to use assistance programs. In Proceedings of the Symposium on Non-Industrial Private Forests: Learning from the Past, Prospects for the Future, Washington, DC, USA, 18-20 February 1996; Baughman, M.J., Ed.; University of Minnesota Extension Services Special Programs: St. Paul, MN, USA, 1996; pp. 264-275.

410. National Woodland Owner Survey; USDA Forest Service, Forest Inventory and analysis Program: Arlington, VA, USA, 2011. Available online: http://www.fia.fs.fed.us/nwos (accessed on 8 July 2011).

411. Yoho, J.G. Needed: An economic definition of the small forest ownership problem. In Proceedings Association of Southern Agricultural Workers 56th Annual Convention, Memphis, TN, USA, 2-4 February 1959; Association of Southern Agricultural Workers: Clemson, SC, USA, 1959; pp. 135-136.

412. Mullins, W.H. The Role of private assistance in the small forestland ownership problem. In Proceedings Association of Southern Agricultural Workers 56th Annual Convention, Memphis, TN, USA, 2-4 February 1959; Association of Southern Agricultural Workers: Clemson, SC, USA, 1959; pp. 136-137.

413. Coutu, A.J. The changing pattern of forestland ownership in the south and the effects on production of forest products. In Proceedings Association of Southern Agricultural Workers 56th Annual Convention, Memphis, TN, USA, 2-4 February 1959; Association of Southern Agricultural Workers: Clemson, SC, USA, 1959; pp. 137-138.

414. Guttenberg, S. Timber demand changes and the south's small forest owner. In Proceedings Association of Southern Agricultural Workers 56th Annual Convention, Memphis, TN, USA, 2-4 February 1959; Association of Southern Agricultural Workers: Clemson, SC, USA, 1959; pp. 138-139.

415. Tarrant, M.A.; Bright, A.D.; Cordell, H.K. Attitudes towards wildlife species protection: Assessing moderating and mediating effects in the value-attitude relationship. Hum. Dimens. Wildl. 1997, 2, 1-20.

416. Bliss, J.C.; Nepal, S.K.; Brooks Jr., R.T.; Larsen, M.D. Forestry community or granfallon? Do forest owners share the public's view? J. Forest. 1994, 92, 6-10. 
417. Kluender, R.A.; Walkingstick, T.L.; Pickett, J.C. The use of forestry incentives by nonindustrial forest landowner groups: Is it time for a reassessment of where we spend our tax dollars? Nat. Resour. J. 1999, 39, 799-818.

418. Belin, D.L.; Kittredge, D.B.; Stevens, T.H.; Dennis, D.C.; Schweik, C.M.; Morzuch, B.J. Assessing private forest owner attitudes toward ecosystem-based management. J. Forest. 2005, 103, 28-35.

419. Straka, T.J.; Wisdom, H.W.; Moak, J.E. Size of forest holding and investment behavior of nonindustrial private owners. South. J. Appl. Forest. 1984, 8, 495-496.

420. Nonindustrial Private Forests: A Review of Economic and Policy Studies Symposium Proceedings, Durham, NC, USA, 19-20 April 1983; Royer, J.P., Risbrudt, C.D., Eds.; School of Forestry and Environmental Studies, Duke University,: Durham, NC, USA, 1983.

421. Sampson, R.N.; DeCoster, L.A. Public Programs for Private Forestry: A Reader on Programs and Options; American Forests Forest Policy Center: Washington, DC, USA, 1997.

422. McColly, R. Consulting foresters' perspectives. In Proceedings of the Symposium on Non-Industrial Private Forests: Learning from the Past, Prospects for the Future, Washington, DC, USA, 18-20 February 1996; Baughman, M.J., Ed.; University of Minnesota Extension Services Special Programs: St. Paul, MN, USA, 1996; pp. 34-36.

423. Cubbage, F.W. Public regulation of private forestry: Proactive policy responses. J. Forest. 1991, 89, 31-35.

424. Johnson, R.L; Alig, R.J.; Moore, E. NIPF landowners' view of regulation. J. Forest. 1997, 95, 23-28.

425. Martus, C.E.; Haney Jr., H.L.; Siegel, W.C. Local forest regulatory ordinance trends in the Eastern United States. J. Forest. 1995, 93, 27-31.

426. Greene, J.L.; Siegel, W.C. The Status and Impact of State and Local Regulation on Private Timber Supply; General Technical Report RM-255; USDA Forest Service, Rocky Mountain Forest and Range Experiment Station: Fort Collins, CO, USA, 1994.

427. De Steiguer, J.E. Impact of cost-share programs on private reforestation investment. Forest Sci. 1984, 30, 697-704.

(C) 2011 by the authors; licensee MDPI, Basel, Switzerland. This article is an open access article distributed under the terms and conditions of the Creative Commons Attribution license (http://creativecommons.org/licenses/by/3.0/). 